\title{
PARADIGMAS HISTORICISTAS DE LA CIVILIZACIÓN OCCIDENTAL: LOS FENICIOS EN LAS COSTAS MEDITERRÁNEAS DE ANDALUCÍA
}

\author{
CULTURE-HISTORICAL PARADIGMS OF THE WESTERN CIVILISATION. THE \\ PHOENICIANS ON THE MEDITERRANEAN COAST OF ANDALUSIA
}

\author{
por \\ OSWALDO ARTEAGA
}

RESUMEN En este trabajo se presentan, de una manera más detallada, los puntos de vista expuestos por el autor en su ponencia al IV CONGRESO INTERNACIONAL DE ESTUDIOS FENICIOS Y PÚNICOS, celebrado a comienzos del mes de Octubre de 1995 en la ciudad de Cádiz. Desde la perspectiva de la historiografía de los últimos cien años de arqueología en la Península Ibérica, se realiza un estudio crítico acerca del concepto de Estado en el mundo fenicio occidental: explicitando las causas ideológicas de su negación, por parte de la investigación especializada, en atención a los paradigmas civilizatorios reproducidos en España por el Historicismo Cultural.

ABSTRACT In this work, the author shows in detail, the points of view developed in his presentation to the IV International Congress of Phoenician and Punic Studies, which took place at the beginning of October in 1995 in Cádiz. In the same way, a critical study is realized about the concept of State in the Phoenician Occidental World from a historiographical perspective in the last hundred years of the archaeology in the Iberian Peninsula: Specifying the ideological causes of its negation, on the part of the specialized investigation, in relation to the Civilizing paradigms reproduced in Spain by the Cultural Historicism.

\section{INTRODUCCIÓN}

La celebración del IV CONGRESO INTERNACIONAL DE ESTUDIOS FENICIOS Y PÚNICOS, en la milenaria ciudad de Cádiz, ha brindado el marco idóneo para la realización de un balance general sobre las investigaciones arqueológicas llevadas a cabo durante los últimos cien años en las costas mediterráneas de Andalucía. 
Como miembro del Comité Científico del Congreso de Cádiz, al autor aquí firmante le fue encomendada la exposición de la reseña historiográfica referida al citado litoral, que de una manera resumida se hizo pública la tarde del Acto Inaugural, el día 2 de Octubre de 1995.

La primera alternativa que teníamos a la hora de redactar nuestro trabajo, era la corrientemente utilizada por los comentaristas de recopilaciones bibliográficas: tomar unas notas de las actividades arqueológicas publicadas, ordenarlas cronológicamente, y resumir algunos resultados. La segunda, también aplicada por historiógrafos más comprometidos, tenía como recurso "la selección de algunas autoridades sobre el tema", para una vez agrupadas sus obras en el tiempo reseñar las propuestas más significativas, y aplicarles un juicio valorativo, desde la posición personal de quien las mira retrospectivamente. La tercera posibilidad, en tanto que las anteriores habían sido desarrolladas hacía poco, respecto de la historiografía fenicia y púnica en Andalucía, era la de abordar el cuestionamiento bibliográfico analizándolo desde la perspectiva del contexto sociohistórico e ideológico de su producción. Nosotros elegimos esta última opción, por parecernos más congruente con la dialéctica del proceso investigativo, dentro del cual también nos hemos visto inmersos en las últimas décadas.

No habiéndose podido incluir el contenido íntegro del texto original en las Actas Oficiales del Congreso, nos ha parecido oportuno darlo a conocer en la revista Spal, todavía en consonancia con el momento del debate dentro del cual se pueden entender las consideraciones planteadas. En efecto, de una manera consustancial con el estado actual de la investigación arqueológica en Andalucía, los objetivos principales que nos propusimos abordar en nuestra ponencia, fueron los siguientes: a) Actualizar la información arqueológica que tenemos sobre los fenicios y púnicos en las costas mediterráneas de Andalucía, para mostrar las razones por las cuales han sido los descubrimientos realizados en dicho litoral los que hasta ahora (desde los tiempos de Luis Siret) no han dejado de marcar las pautas explicativas del proceso histórico fenicio occidental. b) Realizar la reseña historiográfica desde la panorámica sociohistórica propia de los investigadores que consignaron su producción en la bibliografía, para mostrar cuáles han sido las posturas teóricas que más han resultado dominantes, en el contexto de los debates suscitados. c) Revisar el estado presente de los estudios fenicios y púnicos, desde la perspectiva atlántico-mediterránea de su mundo occidental, para insistir de una manera reiterativa (Arteaga 1993-1994) en la valoración histórica de Gadir, dentro del concierto de la llamada "Civilización Occidental", que apoyada en la visión parcial del paradigma greco-romano no ha dejado de acallar expeditivamente la versión más occidental de su proceso. $\mathrm{O}$ sea, la versión que siendo no menos ontológicamente válida ha permanecido históricamente oculta, y hasta negada, por no haberse convertido en paradigma de las ideologías dominantes.

Nuestra toma de postura queda centrada en atención al tercer objetivo de la ponencia, no solamente enfatizando el relevante papel histórico de los ignorados fenicios occidentales, que al lado de Gadir llenaron siete siglos de expectativas atlántico-mediterráneas, en las recónditas nociones de la ecúmene griega y de la finisterre del Mare Nostrum romano, sino también remarcando en concreto las resultantes del proceso histórico fenicio y púnico: que por un lado competen al desarrollo de las formaciones sociales prerromanas en las costas mediterráneas de Andalucía, y al mismo tiempo a la transformación antrópica del medio litoral en cuestión, desde la antigüedad. Ya que, en definitiva, es en el suma y sigue del paisaje cambiante donde se conforma también la "memoria histórica del medio" que hemos heredado las sociedades actuales. Desde esta perspectiva de presente (pero no presentista) pensamos que la teoría funcionalista del espacio, como la teoría estructuralista del paisaje, pueden quedar debatidas desde la proyección dialéctica del proceso histórico, que nosotros plasmamos en la teoría del espacio social: el territorio (Arteaga 1993-1994). 
Como ahora se sabe, la fachada litoral comprendida entre la desembocadura del río Almanzora en la actual Provincia de Almería, y el Estrecho de Gibraltar señalado por el famoso "Peñón", había quedado integrada por los fenicios, a partir del siglo VIII a. C., en una territorialidad socioeconómica, sociopolítica y sociocultural asimilada al mundo colonial gaditano (Arteaga 1992a; 1993-1994). Las más relevantes capitalidades que al lado de Gadir iban a despuntar más tarde como "poleis" en dichas costas (Arteaga 1990: 431-469) no iban a ser otras que las actualmente identificadas con Málaga, Almuñécar, Adra y Villaricos, entre otras; que bajo sus modernos crecimientos urbanos han dejado soterradas las arquitecturas muertas de aquellas viejas ciudades, que hace tanto tiempo las precedieron.

Ya desde la implantación de los catastros romanos se introdujeron nuevas ordenaciones en los sectores urbanos y rurales, que le impusieron una estructuración cambiante a la organización social de estos espacios litorales. Por lo que cabe colegir que los posteriores paisajes medievales y los paisajes castellanos no hicieron otra cosa que acabar de convertir la fisonomía del paisaje fenicio-púnico en una cuestión de geoarqueología (Arteaga y otros 1985; 1988).

En el presente correlato vamos a intentar reseñar los enfoques teóricos que los arqueólogos hemos venido adoptando, en atención a la reconstrucción de este proceso histórico: qué por una parte se refiere a las sucesivas estructuraciones sociales del paisaje litoral, y por consecuencia también a la progresiva transformación del medio costero, como antes hemos dicho.

De una manera retrospectiva, pero comprometida con la explicación de las resultantes sociohistóricas relativas al litoral mediterráneo que ahora nos ocupa, vamos a procurar remarcar hasta que punto muchas de las interpretaciones arqueológicas que se han producido en los últimos cien años, en relación con aquellos paisajes históricos, no han dejado de entrañar en su discurso una contienda ideológica: que ha incidido en una proyección presentista de los mismos, por parte de sus estudiosos; que así no han evitado hacerlos suyos, para ponerlos al servicio de unos parámetros gnoseológicos (teoría del conocimiento), ontológicos (teoría de la realidad) y lógicos (metodología) a todas luces contrapuestos e irreconciliables. Es decir, cayendo la mayoría de las veces en unas interpretaciones historicistas, que nada tienen que ver con el planteamiento de unas explicaciones históricas.

En la trayectoria historiográfica que referimos, salta a la vista que (hasta la última década) las corrientes interpretativas dominantes estaban encardinadas por el cauce del Historicismo cultural. Por lo que sin perder de vista las adopciones difusionistas, evolucionistas, positivistas y normativistas que vamos a reseñar, será interesante observar cómo a expensas de tales aplicaciones el Historicismo Cultural ha logrado mantenerse "vigente". Ya que arropadas bajo su cobertura las citadas teorías culturales no habían sido cuestionadas, en profundidad, por parte de las teorías sociales, hasta hace bien pocos años.

Llegados a este convencimiento, pensamos que cabe expresar aquí que nuestro enfoque no concuerda con las visiones culturalistas a las cuales acabamos de aludir, en tanto que actualmente asumimos una postura crítica frente a las mismas, desde la alternativa teórica de la Arqueología Social. Esta toma de postura teórica se intentará contrastar, de una manera coherente, en el presente estudio (Lumbreras 1974; Bate 1982; Sanoja 1984; Sanoja y Vargas 1984; Veloz 1984; Vargas 1990).

Esperamos así mostrar las razones, a su vez sociohistóricas, por las cuales muy distintos presupuestos teóricos fueron conceptualmente constitutivos de unas diversas alternativas interpretativas y explicativas de la historia fenicia occidental: con la convicción de que solamente asumiendo una debida tolerancia ante las posturas contrarias, podrán encontrar nuestras alternativas un marco adecuado para la crítica constructiva en consonancia con el futuro investigativo que la sociedad presente nos demanda. 


\section{I.- LA POTENCIACIÓN DE UN PRIMER PARADIGMA: ARIOS CONTRA SEMITAS}

La historia de la Arqueología de Campo en las costas mediterráneas de Andalucía no comienza hasta finales del siglo XIX; conociendo la temática fenicia una larga etapa de preludio, que se remonta cuando menos hasta el siglo XVI.

Los primeros estudios que podemos referir a una historiografía de orientación nacionalista, enmarcada en la formación del Estado Moderno, caracterizado por la ideología de la monarquía absoluta, propia del Antiguo Régimen, sin ignorar otros enfoques de corte básicamente eclesiástico (Mariana 1592-1605) se vinieron consignando más que nada en relación con el problema planteado por la erudición en atención a la Tarsis bíblica. Pero pronto no faltaron los hallazgos fortuitos que permitieran especular con la presencia de aquellos pueblos orientales en las costas andaluzas, a tenor sobre todo de las monedas de Malaka, Sexi y Abdera.

Aparte de la literatura publicada, durante el siglo XVII, otras evidencias materiales continuaron siendo más bien escasas, y así poco valoradas. Las aportaciones más relevantes que se dieron hasta el siglo XVIII, apoyándose en la contrastación de las inscripciones monetales, fueron entre otras las tocantes al alfabeto fenicio (Pérez Bayer 1772), y las que potenciaron conceptualmente los pensadores ilustrados.

En efecto, también en España los esquemas "iluministas" comenzaron a traducir las preocupaciones de la Europa de la Ilustración, respecto de los mecanismos de difusión de los conocimientos culturales y de las artes; haciendo del mundo clásico "un nuevo espejo con el cual analizar el presente, y valorar los tiempos pretéritos" (Cruz y Wulff 1994: 177).

Estos planteamientos, hacia el siglo XVIII, se contraponen también con otras visiones como las de los hermanos Rodríguez Mohedano y las de J. F. Masdeu, en las que los fenicios quedaban a su vez sobrevalorados, desde el sur peninsular, para hacer así de Andalucía (antes de la llegada de los griegos y de los romanos) un foco de culturización de primera magnitud, respecto del resto de la Península Ibérica, y por consiguiente respecto de Europa (Cruz y Wulff 1994: 178).

Se fue generando entre el siglo XVIII y el siglo XIX, por otra parte, la consolidación de un tema central de debate: los arios contra los semitas, en la "palestra" historicista europea (Bernal 1987).

La arqueología fenicia, como tal, no había iniciado todavía su andadura; preparándose su gestación de una manera incipiente ya bien entrado el siglo XIX, en el seno de una producción historiográfica bastante condicionada por la exégesis de las antiguas fuentes escritas, y por la mayor ponderación que la erudición le fue prestando a la valoración culturalista greco-romana. Como se ha venido poniendo en evidencia, "la Antigüedad Clásica fue un argumento de autoridad, que desde el Renacimiento se mantuvo durante siglos. Se la consideró un modelo digno de ser imitado, sus lenguas se incorporaron a la educación y sus hallazgos literarios, plásticos o filosóficos fueron un punto de referencia inexcusable" (Beltrán y Gascó, eds. 1994: prefacio). Sobre todo, respecto del pasado que luego queremos referir, resulta evidente que los llamados tiempos clásicos han sido utilizados para el ensalzamiento de una prosapia de prestigio, al servicio presentista de una creación de "identidades, símbolos y puntos de referencia para los pueblos y ciudades de Andalucía” (Gascó 1994: 28). Pero esto mismo, como veremos a continuación, el presentismo se estaba potenciando en relación con toda Europa, en los términos de unas mayores pretensiones civilizatorias. Primero, en justificación de los nacionalismos europeos contemporáneos. Segundo, en justificación de los colonialismos en el Tercer Mundo, y de los modelos civilizatorios consiguientes. Nosotros nos vamos a centrar en los asuntos concernientes al Mundo Antiguo, para cumplir con el objetivo de nuestro trabajo, dejando solamente aquí consignada de pasada la afirmación de que la utilización del pasado, para la justificación del presente, ha tenido en Europa unas connotaciones más graves que las arriba apuntadas. Y sobrados casos tendremos para observar, 
hasta qué punto, la arqueología no ha dejado de hacerse partícipe de tales manipulaciones ideológicas de la Historia: al servicio de las pretensiones "civilizatorias" modernas.

El cultivo historicista de la antedicha visión greco-romana, respecto de la civilización occidental (Arteaga 1993-1994) comporta el fundamento de un paradigma decimonónico europeísta, que todavía no acabamos de romper. Desde un principio, supuso la animadversión de los historiadores occidentales contra los supuestos culturales entroncados con los pueblos semitas (Bernal 1987; López Castro 1992; Arteaga 1993-1994) de los cuales fueron los fenicios y los púnicos los más preclaros representantes mediterráneos, en la antigüedad.

Como lo ha definido Thomas Kuhn, un paradigma "es lo que los miembros de una comunidad científica comparten; $y$, recíprocamente, una comunidad científica consiste en hombres que comparten un paradigma" (Kuhn 1962).

Esto precisamente ha venido ocurriendo con el desenvolvimiento del paradigma grecorromano de nuestra civilización occidental. La europea; que los arqueólogos e historiadores comenzaron a compartir respecto de la Península Ibérica, y nuestras academias han reproducido hasta el presente, en detrimento de otros "enigmas en pugna", que sin ninguna objetividad fueron relegados a planos secundarios, cuando no ignorados por completo, a pesar de formar parte del mismo proceso histórico (Arteaga 1993-1994).

La ruptura del paradigma grecorromano, dado lo que ahora entraña, no puede resultar fácil para las más acendradas posturas que todavía lo enarbolan, como un enfoque inconmensurable. Pero tampoco es menos cierto, que, siendo un enfoque relativista, permite la viabilidad de otras tomas de posturas teóricas (Gándara 1994), que superando incluso la circularidad del concepto del paradigma de Kuhn formulen unas nuevas evaluaciones comparativas y otras potencialidades heurísticas, para la recuperación dialéctica de esos "enigmas en pugna": que tan importantes son para la integración atlántica-mediterránea de los fenicios occidentales, en el concierto histórico que les corresponde (Arteaga 1993-1994).

\section{II.- FILOSEMITISMO Y FILOHELENISMO, EN LA NACIENTE ARQUEOLOGÍA MEDITERRÁNEA DE ANDALUCÍA}

La arqueología de campo fenicia y púnica, como acabamos de exponer, no comienza a desarrollarse en las costas andaluzas hasta finales del siglo XIX. No surge como producto de un proyecto investigativo, institucionalizado, sino más bien debida a otras iniciativas particulares. En el mes de enero de 1890 empezaron las excavaciones en la necrópolis de Villaricos, por parte del ingeniero belga Luis Siret Cells, y siete años más tarde aparecieron publicados los descubrimientos referidos a la necrópolis de la Punta de la Vaca, en el entorno gaditano (De Laigne 1897). El mismo Siret, tuvo que "hacerse" como arqueólogo, de una manera autodidacta, para lograr que sus descubrimientos entrasen en la coyuntura sociohistórica del debate científico, de una manera homologable.

El nacimiento de la arqueología fenicio-púnica peninsular, por consiguiente, quedaría inscrito por parte de sus pioneros en el seno de un debate candente; dentro del cual se estaban conformando definitivamente las tendencias conceptuales que sobre la paleoetnología y la formación de los pueblos europeos iban a resultar dominantes a partir de comienzos del siglo XX. Como se ha dicho, la mala prensa que tuvieron los fenicios y los cartagineses en la literatura grecolatina (Tarradell 1965: prólogo) sería reproducida por la antes mencionada historiografía europeísta (Bernal 1987); aparte de que no faltasen otras valoraciones acerca del papel jugado por los pueblos semitas, en el mundo antiguo mediterráneo (Movers 1841-1850; Meltzer 1878-1896; Rawlinson 1889; Pietschmann 1889). 
La promoción de una interpretación bastante sesgada, con la intención de subrayar de una forma paradigmática la preponderancia de Grecia y de Roma en la consolidación del modelo de progreso europeo, fue primando cada vez más en el desarrollo de la literatura comprometida con los más relevantes presupuestos nacionalistas: a la hora de justificar las proyecciones colonialistas que los mismos estaban llevando a cabo desde Europa; presentando a la sociedad burguesa y al capitalismo industrial como los más preclaros herederos del modelo civilizatorio a seguir; erigiéndolo desde unos cimientos clásicos.

Muy poca entrada podían encontrar en estos modelos del "progreso", los pueblos semitas identificados con los fenicios y cartagineses; entonces igualmente mirados con aires superiores desde Europa.

$\mathrm{Al}$ introducirse en tan peliagudo campo Luis Siret, como bien lo comenta Gerald Brenan en su libro "Al Sur de Granada", estaba percatado de que por entonces "denigrar de los fenicios se había convertido en una manía". Y sintiéndose atacado por quienes incluso ponían en duda los resultados de sus excavaciones, fue por lo que Siret llegaría a expresar, criticando las "envidias y celos de los arqueólogos" la célebre frase: "Ce n'est pas une Science, c'est un combat á mort". Mostrándose convencido de que aquella situación era debida "al antisemitismo de los sabios".

Sin duda alguna, como veremos a continuación, fueron los sabios más representativos de los principales "círculos científicos", aquellos destacados propulsores de las emergentes academias clásicas (como la Altertumswissenschaft en Alemania) los que durante el siglo XIX-XX mayor influencia ejercieron en el desarrollo oficial de los estudios de la Arqueología y de la Historia Antigua, en el Occidente europeo. Razón por la cual, además de otras muchas aducibles, las propuestas decimonónicas de Siret, respecto de los fenicios y cartagineses en las costas andaluzas, iban a conocer bien pronto el contrapunto academicista de la tradición tardo-romántica, representada en España por Adolf Schulten (Tarradell 1975; Cruz 1987; Blech 1995).

Mientras que Luis Siret, en cualquier caso, venía buscando entroncar la historia del Mediodía peninsular con los pueblos semitas, Schulten se afanaría en buscar el origen de la más antigua civilización occidental, la tartesia, primeramente en los pueblos cretenses (Schulten 1924) y después en los pueblos tirsenos del Asia Menor (Schulten 1945). Mientras que para Siret los fenicios y los cartagineses fueron los representantes de la corriente civilizadora oriental, que los Celtas tuvieron que contrarrestar en el teatro de España, para convertirse éstos últimos en "campeones de la resistencia del Occidente" (Siret 1907: 39); para Schulten, aquellos mismos pueblos, no habían hecho otra cosa que interrumpir con su codicia la vertebración tartesia con sus raíces helénicas. Los fenicios lo habrían hecho, derrotando al rey Gerión, a comienzos del siglo VIII a. C. (Schulten 1924). Y por su parte, los cartagineses lo habrían repetido, destruyendo a Tartessos y a Mainake (Schulten 1924), una vez que los foceos habían retomado las buenas relaciones griegas con el rey Argantonios.

En definitiva, las dos tendencias, una filosemita cada vez más relegada, y otra filohelénica cada vez más propugnada, quedaron implantadas en la naciente arqueología andaluza: entre la primera Guerra Mundial y la Guerra Civil española.

Los pueblos fenopúnicos frente a los griegos y romanos; el historicismo celtibérico de Siret, junto al romanticismo academicista de Schulten; Villaricos frente a Mainake. He aquí los polos referentes del debate arqueológico, que en atención a las interpretaciones culturalistas más iban a interesar a los estudiosos especializados, hacia la primera mitad de nuestro siglo. 


\section{III.- LAS EXPECTATIVAS PANGERMANISTAS Y FILOHELÉNICAS EN LA ARQUEOLOGÍA HISPANA: ANTES Y DESPUÉS DE LA GUERRA CIVIL ESPAÑOLA}

En atención al marco ideológico dentro del cual vamos a movernos a continuación, vale la pena que no perdamos de vista que la llamada revolución liberal-burguesa (1808-1874) ha tenido un peso historiográfico notable, que iba a notarse durante los tres primeros cuartos del siglo XX, respaldado por la llamada burguesía industrial democrática, en la misma medida en que la burguesía conservadora (1874-1931) abandonaba tales planteamientos "revolucionarios", para asumir otros cada vez más autoritarios. La cota máxima de la contienda ideológica llega con la II República y con la Guerra Civil, de la que surge el régimen nuevo, vinculado a la Era de Franco (1931-1970/1975). Esta es la matriz general del discurso, en el seno del debate propio de la burguesía contemporánea. Sigamos ahora observándolo, en atención a las expectativas de la Arqueología que estamos comentando.

Lo primero que salta a la vista, a tenor del reclamo que plantean los estudios más recientes, es que a raíz de los tiempos que significamos en unas obras tan señeras como las de Luis Siret, y las de Adolf Schulten, los conocimientos históricos de las llamadas colonizaciones fenicias, púnicas y griegas, en las costas mediterráneas de Andalucía, eran dependientes de un debate mucho más proclive a las interpretaciones culturalistas, de corte decimonónico, que a la búsqueda de parámetros explicativos para la construcción de una teoría social, críticamente contrastable.

Las estrategias filosemitas y filohelénicas, para la edificación de aquellos discursos, al apoyarse en los criterios difusionistas que los citados investigadores iniciaron y sus seguidores/opositores retomaron, no hicieron otra cosa que consolidar el "idealismo" propio del Historicismo Cultural.

El mejor punto de partida, desde las perspectivas apuntadas por Siret, lo encontramos consignado en su obra emblemática sobre "Villaricos y Herrerías" (Siret 1907) que recientemente ha sido reeditada, y por nuestra parte comentada (Arteaga 1995: XI-XXX). En tanto que las propuestas apuntadas por Schulten aparecen ampliamente formuladas en su obra sobre "Tartessos" (Schulten 1924); siendo no menos ilustrativa la postura asumida antes por Jorge Bonsor, en "Les colonies agricoles pré-romaines de la Vallée du Bétis" (Bonsor 1899).

La contrastación de las visiones interpretativas mantenidas por investigadores como Siret, Bonsor y Schulten, en la transición del siglo XIX al siglo XX, donde mejor se encuentra consignada es sin duda en la perspectiva que asume por su parte Pedro Bosch Gimpera: que sobre todo desde los años veinte en adelante iba a ejercer una relevante maestría, en el campo investigativo de la protohistoria de la Península Ibérica. En 1932, marcando un hito en el estudio de los pueblos primitivos hispanos, apareció publicada su obra "Etnología de la Península Ibérica". Como nadie hasta entonces, Bosch Gimpera se iba a ocupar de sintetizar las perspectivas mediterráneas y continentales; que a su entender resultaban fundamentales para la explicación de los "orígenes" de los pueblos y culturas (ibéricas y célticas) de la España Antigua. En modo tal que las propuestas siretianas, sin quedar rechazadas en extremo, fueron matizadas desde las colonizaciones marítimas, fenicias, griegas y púnicas, y desde las llamadas invasiones transpirenaicas (Bosch 1932).

Sin perder de vista las directrices magistrales apuntadas por Bosch Gimpera, hasta después de la Guerra Civil española, casi todas las interpretaciones conciliadoras de las distintas posturas difusionistas, que se fueron generando en el seno de la arqueología peninsular, intentaban todavía como Siret homologar la integración de las investigaciones andaluzas en un marco civilizatorio europeo y mediterráneo. 
La Península Ibérica sería contemplada como un punto de encuentro de las citadas colonizaciones fenicias y griegas, éstas llegando por el mar, y de las cada vez más aceptadas "invasiones" célticas, éstas llegando a través de los pasos pirenaicos (Bosch 1932; 1945).

Como había adelantado Siret, aunque ahora distintos autores lo hicieran con nuevas argumentaciones historicistas, se trataba de matizar una visión etnológica y etnográfica acerca de la formación de una gran nación celtibérica: conquistada luego por los púnicos, romanos, visigodos, bizantinos, y finalmente por los árabes (Siret 1907). Cobrando con ello, en atención al Mediodía peninsular, una mayor justificación las "razones" aducibles para dimensionar la Reconquista: que los historiadores especializados en los tiempos de los Reyes Católicos no dejaron de concatenar con el destino histórico de la España Moderna.

La intencionalidad ideológica de la "identificación" de la nación moderna, con la celtibérica, se puso de manifiesto en la proyección virtual de dicha nación moderna hacia el pasado: estabilizándola, como si su realidad presente no dependiera de las condiciones históricas propias del mundo contemporáneo.

Hasta bastante después de la Segunda Guerra Mundial, los discursos difusionistas sobre los "orígenes" de los pueblos y culturas, al servicio de las etnografías así pergeñadas, aparte de las reacciones que también se motivaron, respecto de la "lingüística" en atención a las "raíces" del pueblo vasco (Caro Baroja 1946: 69-73) y en "defensa" del iberismo (Fletcher 1949) resultaron sumamente decisivos a la hora de sistematizar las causas motrices de las manifestaciones culturales relativas a la Protohistoria y a la Historia Antigua de España.

Como lo señala recientemente A. Ruiz (1994: 195), el debate de las Dos Españas reverdece. Por una parte estaban los planteamientos nacionalistas, con particulares transpersonalismos de valores, que en contados casos abrieron las puertas al fascismo (Tuñón de Lara 1970). Y por otra parte estaban los nacionalismos anti-centralistas. Para los primeros, la identificación con el pasado quedaría asentada en la idea del pueblo prerromano: como "fuerte, trabajador y disciplinado", que para su vida habría tenido como estímulo dos grandes ideales; "que tal vez no se han extinguido aún del todo en nuestra raza, a saber: entusiasmo por su independencia, y ansia por un vivo culto religioso" (Calvo y Cabré 1919: 14). Del lado de los segundos, en lugar de la noción aglutinante del espíritu prerromano con lo hispánico (Cabré 1925), se mantiene otra visión poliétnica, como la sustentada por Bosch Gimpera (1932: 14), y por sus discípulos, según la cual las realidades culturales de la Península Ibérica se habrían conformado gracias a las pervivencias de un mosaico de fenómenos particulares. Los catalanes remanecerían de los íberos, los aragoneses de los celtíberos y los andaluces de los tartesios; en contra de los valores remitidos por otros autores a la idea de la unidad de España (Cortadella 1988).

Es a partir de entonces, por lo tanto, cuando en el transcurso de la post-guerra las perspectivas pangermanistas de las invasiones centroeuropeas (Martínez Santaolalla 1946; Almagro 1952) estrecharon como nunca sus lazos interpretativos con las perspectivas griegas mediterráneas (García y Bellido 1948; Almagro 1953): estas últimas analizadas desde unos criterios no menos difusionistas que los propugnados hasta entonces, por las otras versiones de "ex Oriente lux".

La fundación de Ampurias, en efecto, se convierte en una referencia obligada para inferir los orígenes clásicos de la Cultura Ibérica. Los invasores indoeuropeos, como los griegos jonios, se situaron en los primeros planos del interés arqueológico.

Por lo cual, como escribe J. L. López Castro (1990: 20), a partir de la citada contienda civil la investigación de la colonización griega en la Península Ibérica, "como excelente y prestigioso antepasado de España, y como fenómeno histórico más presentable para los propósitos legitimadores del régimen", cobraría un nuevo impulso con las excavaciones de Ampurias (Almagro 1953).

Dentro de este nuevo orden de cosas, en consonancia con la Academia de la década de los años cuarenta, y apoyándose en las pocas evidencias arqueológicas entonces existentes, Antonio García y Bellido, maestro de maestros de la Arqueología Clásica y de la Historia Antigua de España, tradujo 
claramente en su interpretación de las fuentes escritas grecolatinas la transición conceptual apuntada, en favor y en contra de las perspectivas fenicias y griegas. Primero, en su obra "Fenicios y Cartagineses en Occidente" (García y Bellido 1942), en la que no oculta la prevalencia que le otorgaba a la colonización griega, de cara al desenvolvimiento de la Historia Antigua de España. Y después en su "Hispania Graeca", en la cual sus posturas filohelénicas aparecen mucho más decantadas (García y Bellido 1948).

La abundante literatura que por entonces aparece, afirmando el dominio del paradigma grecorromano, para interpretar la Historia Antigua de España, desde las expectativas culturales del Mundo Clásico, no deja de afectar a la materia arqueológica de su investigación, que por su parte se precipita en la búsqueda de confirmación de aquellos mismos dictados (García y Bellido 1943).

La construcción histórica de HISPANIA, como la reivindicación del propio nombre de España lo exigía, debía fundamentarse pensando paradójicamente en una derivación ideada a través de los presupuestos grecolatinos. Por lo que, darle este contenido arqueológico a las fuentes escritas, era la tarea más interesante que podían emprender los estudiosos de la Arqueología Clásica.

\section{IV.- LA EXALTACIÓN ROMANTICISTA Y NACIONALISTA DEL PARADIGMA GRECO-ROMANO: EN LA ARQUEOLOGÍA DE LOS AÑOS CINCUENTA}

Aparte de algunas voces que de una manera casi solitaria se hicieron sentir (Tarradell 1950; 1951; $1952 ; 1953 ; 1955 ; 1956 ; 1958 ; 1960)$ reclamando para las costas meridionales de Andalucía una vertebración fenicio-púnica con el Norte de África, en torno al Estrecho de Gibraltar, puede afirmarse que la mayor atención de los estudiosos españoles continuaría buscando establecer "relaciones culturales" griegas y romanas, a través del Mediterráneo: con un puente destacado de transmisión situado en Ampurias (Almagro 1953).

Como ya se estaba acusando en la década anterior (García y Bellido 1943; 1948; Cabré 1944; Martínez Santaolalla 1946; Almagro 1952) el relativo interés que se le venía prestando a la colonización fenicio-púnica (García y Bellido 1942; 1948) contrastaba notablemente con el afán que los historiadores y arqueólogos mostraban vinculando la referencia presentista de los españoles con la identificación del pasado grecorromano. Hasta el punto de llegarse a honrar "la memoria del rey de Tartessós, Arganthonios" por considerar que habría sido "el primer español conocido, que supo admirar a Grecia" (García y Bellido 1945).

El lento y retardado conocimiento de España como una entidad geográfica, dentro de la "oikouméne" griega, respecto del foco clásico de la cultura antigua mediterránea, según opinaba García y Bellido (en el prólogo introductorio de su obra España y los españoles hace dos mil años) se habría debido en no poca medida "a la interferencia histórica de un pueblo que, como el púnico, sirvió durante casi toda la Antigüedad de pantalla opaca que impidió que las luces griegas llegasen a iluminar clara y nítidamente estas apartadas regiones..." (García y Bellido 1945). La coincidencia con Schulten, resulta evidente.

El nombre de España, como un elemento central del historicismo justificativo del presente por el pasado, se hace casi insoslayable en relación con los postulados que los respectivos autores asumen ideológicamente. Los títulos de sus trabajos resultan significativos: "El poblamiento antiguo y la formación de los pueblos de España" (Bosch 1945); "Los pueblos de España" (Caro Baroja 1946); "La España Primitiva" (Pericot 1950); "La España Antigua" (Pericot 1958); "Las artes y los pueblos de la España primitiva" (Camón 1954). Siendo sus contenidos conceptuales mucho más elocuentes cuando se comparan con los argumentos expresados en: "La España de las invasiones célticas" (Almagro 1952); 
en España y los españoles hace dos mil años (García y Bellido 1945); y en La España del siglo primero de nuestra Era (García y Bellido 1947).

En consecuencia, lo que cabe subrayar en la historiografía de la década de los años cincuenta es que la producción bibliográfica relativa a la arqueología se continuaba haciendo consonante con la realidad sociopolítica que dominaba en el país: la gestación del Espíritu Nacional.

Siendo la historiografía vista hasta los años precedentes una historia de la historia concebida por los historiadores, la que se consigna en el mencionado decenio español no puede resultar más proselitista.

Se produjo con la afirmación del nuevo régimen político una sintomática censura de las obras históricocríticas (Vilar 1947; 1963), a la vez que se hacía más "presentable" una exaltación "literaria", del más puro cuño romanticista y nacionalista: que ideológicamente dejaba centrado su objetivo primordial en "situar" a los españoles en la Historia, como lo expresa R. Menéndez Pidal en su prólogo a la Historia de España, que este mismo investigador dirige para la Espasa-Calpe; contando con la colaboración de los más prestigiosos prehistoriadores, arqueólogos y especialistas del Mundo Antiguo peninsular.

Como se han encargado de poner de relieve otros autores, dada la carencia manifiesta de otras obras generales como la antes citada, los que abundaron en aquella situación fueron los ensayos interpretativos: que en la mayoría de los casos llegaron a la suplantación de la arqueología y de la Historia, por el estudio literario de las fuentes escritas y de las culturas hispanas en abstracto, reinando así por completo el subjetivismo en el desarrollo impertérrito del Historicismo Cultural. No se dejaron de suscitar, sin embargo, llevados a este campo de batalla, muy enconados debates: que en algunos casos marcaron la época. Nos referimos sobre todo a la polémica entre C. Sánchez Albornoz y A. Castro, buscando cada uno por su lado la demostración de lo mismo (Barbero y Vigil 1978: 18): la existencia de un talante hispano ancestral y una esencia trascendente de lo español; fuera basada en un espíritu inalterable desde los tiempos prehistóricos (Sánchez Albornoz 1956), fuera adquirido en un momento posterior, gracias a la "morada vital" nacida por las coincidencias culturales resultantes de la reunión de elementos cristianos, con elementos hebreos y musulmanes (Castro 1966). Mientras tanto, en la prospectiva teórica de los arqueólogos, se estaban produciendo unas ciertas innovaciones, sin romper con los mismos cauces historicistas.

En efecto, cuando la aventura de Schulten en la búsqueda de la mítica ciudad de Tartessos parecía acabada, García y Bellido inicia la contemplación de un "foco de arte peculiar" distinto del ibérico (García y Bellido 1960 ; 1964) al presentar como indígenas unas series de oinochoes de bronce, procedentes del área andaluza (Arribas 1965), que antes eran supuestas como de origen fenicio. Se trataba de una nueva y sugerente línea de interpretación, que seguidamente iban a compartir A. Blanco Freijeiro, E. Kukahn, J. Maluquer de Motes, E. Cuadrado y J. de M. Carriazo. La resurrección de Tartessos se hace de nuevo una "idea muy cara a los arqueólogos españoles" (Arribas 1965: 40).

Un intento de recopilación de los objetos orientales y fenicios existentes en la Península Ibérica, por parte de A. Blanco Freijeiro, publicado bajo el título Orientalia I y II (Blanco 1956 y 1960) nos resume muy bien el estado de la cuestión: en la que el hallazgo arqueológico por su valor intrínseco se convierte en objeto de especulación intelectual, para la interpretación de la cultura y hasta de la civilización. Se hace patente el cultivo de una visión esteticista, para la arqueología, así entendida. Por lo que su desarrollo metodológico, más sublimante que histórico, queda cada vez más emparentado con la Historia del Arte: produciendo para el historicismo, en realidad, la interpretación de un culturalismo elitista. A tenor del estudio de unas piezas tan "relevantes" como las "joyas" (Blanco 1956 y 1960), se trataba de resucitar al lado de los colonos orientales de las costas del mediodía la idea opulenta de Tartessos: como un espejo, crisol y foco de cultura, poniendo ahora en evidencia la necesidad de la existencia de un territorio, suficientemente fuerte y rico "para dar personalidad a estas obras de arte". 
Este centro, "en la encrucijada de estilos orientales y célticos, abierto a todas las influencias, fecundo y personal, hubo de hallarse en la región tartesia" (Arribas 1965: 40).

La interpretación de esta cultura no podía contaminarse en lo "vulgar", realizándose de una manera arbitraria y selectiva a tenor de las citadas manifestaciones artísticas; que también eran culturales pero nobles. Por lo que como nunca fueron las "piezas de museos", aparte de los grandes "monumentos", las que merecieron los mejores estudios especializados; y las que por supuesto permitían a quienes las interpretaban la mostración ufana de un intelecto refinado, acaso para cualificarse mejor como Arqueólogos del Arte.

La carencia de una consistente arqueología de campo al servicio de la Historia Antigua de Andalucía, seguía entonces alimentada por una variable credulidad en las fuentes escritas grecolatinas. Lo cual hizo que los estudios fenicio-púnicos continuaran teniendo unos referentes excavatorios bastante restringidos: en las viejas evidencias gaditanas (Quintero 1917 y 1918-1935) y en las de Villaricos (Astruc 1951).

Los primeros tiempos coloniales, desde la perspectiva de la arqueología de campo, en todas las costas andaluzas brillaban por su ausencia. Nada había todavía excavado, con una metodología precisa, que no perteneciera a la época púnica relativa a los cartagineses. El silencio de las fuentes clásicas, se continuaba haciendo cómplice del silencio arqueológico.

Fue en razón de esta situación por lo que algunos investigadores como Bosch Gimpera y García Bellido, estando por su parte muy atentos a los resultados de Cádiz y de Villaricos, y a los que se sumaron con las excavaciones de Ibiza (Vives 1917; Román 1918-1927) no siendo en ningún caso anteriores al siglo VI a. C., como se ha mostrado hasta épocas más recientes (Tarradell y Font 1975) mantuvieron durante los años cincuenta la hipótesis de que las fundaciones coloniales de Malaka, Sexi, Abdera y Baria, no habrían conocido su apogeo hasta los tiempos púnicos (García y Bellido 1942: 250 y 120 ; Bosch 1945; 1952).

Este criterio de asignarle a los citados asentamientos una preferente atribución cartaginesa, aparte de otras razones concurrentes, cuando se comenzaron a detectar en ellos los niveles pertenecientes a los siglos VIII y VII a. C., resultaría influyente en el hecho de que fueran denominados "paleopúnicos" (Schubart y otros 1966 y 1969), cuando no todavía púnicos (Pellicer 1963).

También una coyuntural terminología grecopúnica, como luego veremos, habría de acusar la transición conceptual que seguidamente se avecinaba, respecto de las costas mediterráneas.

El balance arqueológico de los años cincuenta, en dichas costas mediterráneas de Andalucía, no se puede referir por todo lo antes dicho a ningún cambio espectacular. La tónica general era sumamente parca en resultados. Pero una vez remarcadas éstas circunstancias, que ya fueron acusadas desde Lixus por Tarradell (1952), no podemos afirmar lo mismo a partir de 1960 (Tarradell 1967) cuando la situación de la investigación fenicio-púnica en el Mediodía peninsular iba a conocer una nueva proyección, de dimensiones arqueológicas "revolucionarias".

\section{V.- EL TRIUNFO DEL IDEALISMO POSITIVISTA, AL SERVICIO DE LA ARQUEOLOGÍA FENICIA EN ANDALUCÍA}

Durante la década de los años sesenta, en el seno del Historicismo Cultural, entonces imperante, se comienza a librar una lucha interna entre lo que podríamos llamar un idealismo objetivo dominante, y un idealismo subjetivo opositor. El origen de España, comienza a cuestionarse con una mayor fuerza, desde la postulación pluralista de Las raíces de España. La primera alternativa idealizaba la visión del "origen" de la nación, y la segunda la noción de la "formación" de sus pueblos y culturas. 
Una se basaba en la abstracción de los movimientos difusivos, que se venían construyendo idealmente en el tiempo y en el espacio. La otra se apoyaba en una empiria más evolutiva; que solamente se podría constatar cuando las excavaciones fueran realizadas con criterios estratigráficos.

Las cuestiones hasta entonces referidas a la búsqueda de los "orígenes" de los pueblos y culturas, por lo tanto, comenzaron a plantearse en secuencias estratigráficas, desde diversas perspectivas "formativas". El problema del origen, en la opinión de Maluquer: "sugería de modo inevitable una traslación, un movimiento, una migración (...) para explicar la aparición de un pueblo en un área y en un momento determinado, pues se partía de la consideración de un elemento al que pudiera seguirse la pista a lo largo de una ruta." (Maluquer 1965: 9).

El concepto de la "formación" del pueblo y de la cultura, en cambio, supone para el mismo autor la aceptación de un proceso histórico de continuidad básica: "que no descarta el continuo enriquecimiento y matización, debido a múltiples aportaciones y a la constante reelaboración de elementos, que tienden hacia la cristalización de una determinada cultura, en la que el medio físico, la idiosincrasia humana, y los estímulos exteriores se conjugan armónicamente para formular una personalidad bien definida que es propia de un grupo y destaca frente a otras cristalizaciones semejantes" (Maluquer 1965: 10).

Desde estas nuevas perspectivas "formativas", como ha señalado con acierto A. Ruiz, el idealismo opositor que nosotros referimos no era otro que el propugnado por el método experimental positivista; que con su pretendida "inocencia blanca" y apoyándose en "la España de los tecnócratas", lejos de motivar la crisis de los viejos conceptos, con sus calibrados métodos iba a solapar las bases subyacentes del historicismo, que "reajustando su matriz tradicional continuaría estando presente" (Ruiz 1993: 200-201).

No debemos perder de vista que el debate idealista, así planteado, alineaba por una parte sobre todo a los arqueólogos clásicos, y por otra parte sobre todo a los prehistoriadores. Es decir, que los arqueólogos de campo dedicados al estudio de las culturas y pueblos de la "prehistoria" iban a mostrarse más proclives a la adopción de los métodos estratigráficos.

La década positivista coincide ciertamente con el impacto causado por la publicación en castellano de la Arqueología de Campo de Mortimer Wheeler (1961), que aparecida en 1954 bajo el título Archaeology from the Earth había circulado en España hasta entonces de una manera menos exitosa que la Introducción al estudio de la prehistoria y de la arqueología de campo de Martín Almagro (Almagro 1941-1960=1975). Los argumentos estratigráficos, antes no desconocidos, sirvieron en distintas regiones españolas para acceder a la particular interpretación de sus raíces: las de algunos nacionalismos actuales. Escribir sobre las "raíces de los países" españoles, proyectando sus condiciones presentes al pasado, se iba a convertir en una forma de contribuir a la consolidación "histórica" de la pluralidad hispánica: como si las formas institucionales de las naciones, las costumbres, los matices culturales y las "idiosincrasias" hubieran sido permanentes (Bosch 1945 y 1953). Era la afirmación de la España de todos, que pugnaba por refrendar sus particularismos históricos, frente a las ideologías centralistas reafirmadas a partir de la Guerra Civil (Bosch 1963 y 1972).

En las costas meridionales de Andalucía, la arqueología de campo fenicia y púnica tuvo ahora un desarrollo con expectativas hasta entonces nunca vistas. Y esta eclosión excavatoria, que se habría de proyectar hasta nuestros días, iba a encontrarse presidida por la aplicación de aquellos métodos positivistas; que dadas las carencias metodológicas reinantes pronto se convirtieron en unas actuaciones modélicas, a imitar. Sobre todo, por las técnicas de campo y las analíticas de laboratorio que ellas comenzaron a fomentar.

La arqueología del "gabinete de estudio", a partir de entonces, iba a tener ante ella la alternativa complementaria de una arqueología práctica y experimental; que no todos los estudiosos del Mundo Clásico llegaron a adoptar. La ruptura metodológica, en el seno del Historicismo Cultural, 
quedaba así patentizada. Las primeras cátedras de Historia Antigua que se dotaron y cubrieron a partir de 1966, en España, nacieron y dieron sus pasos iniciales en estrecha relación con la Arqueología Clásica. Razón por la cual la separación metodológica, respecto de la Arqueología Prehistórica, se hizo cada vez más grande.

Desde la muerte de Luis Siret en 1934, el idealismo romántico de la arqueología del "gabinete" se había venido afianzando con sus interpretaciones acerca de los pueblos fenicios y cartagineses, y muy pocos arqueólogos de campo habían continuado llevando a cabo unas contrastaciones directas sobre el terreno, en las costas meridionales de Andalucía (Tarradell 1952). No resulta por ello extraño que el relevo de Siret lo hubieran tomado en sus manos los arqueólogos venidos del campo de la prehistoria, tales como: Manuel Pellicer, Antonio Arribas, Wilhelm Schüle y Hermanfrid Schubart. Los primeros entroncando sus experiencias con la escuela de Martín Almagro, y los segundos con escuelas alemanas.

En definitiva, los sistemas de cortes aplicados por Manuel Pellicer para cubrir amplios espacios horizontales, en la "Necrópolis Laurita" de Almuñécar, fueron los que inauguraron la nueva época de la arqueología fenicia en el Mediodía Peninsular (Pellicer 1963). Siendo la misma confirmada con los sistemas de ejes estratigráficos, dispuestos para crecer en extensión mediante cortes laterales, aplicados por Schubart, Niemeyer y Pellicer, en las excavaciones iniciadas en 1964, por el Instituto Arqueológico Alemán de Madrid, en los asentamientos fenicios de los alrededores de Torre del Mar (Schubart y otros 1969).

Las excavaciones fenicias de Torre del Mar y de su entorno, bien fueran las realizadas hacia la desembocadura del río de Vélez, bien fueran las realizadas hacia el río Algarrobo, por múltiples circunstancias causaron un enorme impacto. Casi nadie se esperaba tan sorprendentes resultados. Ni siquiera los propios arqueólogos que las promovieron.

Las razones que primero animaban a los excavadores, a decir verdad, estaban cifradas en la búsqueda de la presencia griega en la zona; dadas las prospecciones previas efectuadas, y las referencias obtenidas (Niemeyer 1962) siguiendo las huellas de Adolf Schulten: con la intención de encontrar el emplazamiento de MAINAKE (Schulten 1924 y 1945). Pero, en lugar de los griegos, aparecieron los fenicios. Por lo que de esta manera paradójica, gracias a las evidencias tan incuestionables que las excavaciones alemanas pusieron a la luz, aquella década se hizo más bien reivindicativa del papel histórico jugado por los fenicios en las costas mediterráneas de Andalucía, y en todo el Mediterráneo Occidental.

Por lo pronto, la valoración del llamado "impacto" fenicio contribuyó a que se moderase la valoración protagonista que, en extremo, se estaba otorgando a los griegos. Para estos últimos se mantendría desde entonces, respecto de los navegantes foceos, el reconocimiento de una talasocracia comercial, durante el reinado de Argantonios en Tartessos (Herodoto I: 163). En tanto que para los fenicios quedaría reconocida la colonización propiamente dicha. Así como también el hecho de haber comenzado la explotación del territorio costero, que después heredaron los fenicios occidentales, que allí se naturalizaron.

Las investigaciones promovidas con la colaboración del arqueólogo clásico H. G. Niemeyer en Toscanos (Schubart, Niemeyer y Pellicer 1969), Cerro del Mar (Schubart y otros 1969: 22-36), Trayamar (Niemeyer y Schubart 1968: 76-105) y el Morro de Mezquitilla (Pellicer y otros 1966: 246-249), a las que también se sumaron las del Cerro del Peñón (Schubart y otros 1969: 11-21) alcanzaron bajo la solvente experiencia de campo de Hermanfrid Schubart una calidad de escuela internacional, en la que no pocos principiantes de nuestra generación estuvimos agradecidos de aprender su praxis, y de beneficiarnos de su talante crítico. La situación actual de los debates conceptuales, en nuestra Andalucía, habría avanzado en la consecución de una notable mejoría (valga el comentario), si muchos otros maestros de su generación hubieran mostrado una tolerancia crítica por lo menos parecida. 
En otro orden de cosas, cabe añadir que las enseñanzas de Torre del Mar permitieron establecer unas contrastaciones arqueológicas hasta entonces insospechadas: tanto en lo relativo al cotejo riguroso de las fuentes escritas, como en lo concerniente al mundo tartesio-ibérico; que contando ahora con las estratigrafías costeras pudo comenzar a recibir una nueva sistematización (Pellicer y Schüle 1962; 1966). La terminología grecopúnica, se hizo propia de las interpretaciones comparativas, respecto del hinterland.

Las grandes recopilaciones de "datos" y de "hallazgos", por supuesto, no cesaron en su empeño (Blázquez 1968). Pero como hemos apuntado, las pautas del debate, con las nuevas argumentaciones estratigráficas, cambiaron (por otro lado) de una manera radical: claro está, siempre en relación con las otras "metodologías" especulativas, entonces imperantes. Muchos fueron los que siguieron colocando sus objetos arqueológicos en los "contextos idealizados" de sus propuestas, mientras que otros empezaron a colocarlos en "contextos estratificados" para su posterior interpretación. Aquéllos tomaban para sus hipótesis esquemas evolutivos ideados desde unos descriptivos "desarrollos tipológicos", y éstos buscaban secuencias relativas para asegurar la cronología de los suyos.

En fin puede verse claramente, como hemos remarcado, que el debate interno del Historicismo Cultural, en términos objetivos y subjetivos era de cualquier modo idealista. Los primeros partiendo del campo de la "idea". Los segundos partiendo del "dato" comprobado. Los paradigmas tipológicos y estilísticos, en efecto, fueron sustituidos por los paradigmas estratigráficos. Por lo que unos en la "resistencia", continuaron construyendo su historicismo desde unos idealismos reductores del mundo pretérito a los conceptos: como independientes de los fenómenos materiales. Mientras que sus "opositores" pasaban a construirlo admitiendo solamente lo constatado empíricamente por su método, rechazando toda noción a priori, para hacer del mundo investigado un producto de sus comprobaciones.

No resultaba en ningún modo probable, a la vista de la perspectiva sociohistórica española, en los años sesenta, que se pudiera haber dado una apertura teórica más proclive a otras alternativas. Por lo que la nueva cualificación del idealismo historicista vino dada por la metodología positivista. Nada puede cambiar, desde luego, dialécticamente de la nada.

\section{VI.- EL NORMATIVISMO EN FUNCIÓN DE LA “IRRADIACIÓN CULTURAL” FENICIA Y PÚNICA EN OCCIDENTE}

Desde mediados de los años sesenta, los descubrimientos arqueológicos fenicios y púnicos, en las costas mediterráneas de Andalucía, se continuaron produciendo de una manera acelerada. Una vez que se consolidaron los resultados positivistas de Almuñécar y de la Axarquía de Málaga, los conceptos normativos de la culturización comenzaron a ser aplicados para interpretar la "irradiación" de la civilización fenicia en el hinterland. Ya que se había patentizado que la franja litoral ubicada entre Baria (Villaricos) y Gadir (Cádiz) estaba ocupada y explotada por los fenicios, en base a territorios dominados desde centros como Malaka, Sexi, Abdera y la citada Baria.

Destacaron entre otras las excavaciones practicadas en asentamientos y necrópolis como los de: Cerro del Villar en Guadalhorce (Arribas 1969); Cortijo de las Sombras de Frigiliana (Arribas y Wilkins 1971), Necrópolis Jardín (Schubart y Niemeyer 1969-1970), Trayamar (Niemeyer y Schubart 1968) y Cerro del Alarcón (Schubart y otros 1972), continuándose las no menos relevantes de Toscanos (Niemeyer y Schubart 1968), Morro de Mezquitilla (Schubart 1976-1978) y las del Cerro del Mar (Gamer 1972).

En el curso de los años setenta el acopio de información se hizo todavía mayor, confirmándose la especial singularidad del proceso histórico referido a los fenicios occidentales (Arribas y Arteaga 1975) 
en la revisión del concepto "paleopúnico", que al principio había sido utilizado para identificarlos (Schubart y otros 1972: 11).

Siendo ya conscientes de que la periferia marítima del Mundo Tartesio estaba ocupada por las colonias fenicias (Schubart y otros 1969) como igualmente percatados de que el poblamiento indígena había conocido un proceso conducente a la Cultura Ibérica (Pellicer y Schüle 1969) distinto al que venían suponiendo muchos autores: pudimos también darnos cuenta por las prospecciones realizadas en los alrededores de Orihuela (Alicante) de que las arqueologías tartesias, ibéricas, fenicias y griegas, podían encontrar su mejor punto de contrastación en la región alicantina del Bajo Segura: razón por la cual iniciamos en colaboración con María Serna las excavaciones en el poblado de Los Saladares (Arteaga y Serna 1973, 1974 y 1975).

En el seguimiento de aquella perspectiva, a la vista del estado en que se hallaban los supuestos de la investigación del iberismo en el País Valenciano (Pla 1959 y 1962: 233-239; Tarradell 1962: 183-185; Llobregat 1969: 31-70; 1972) y sin olvidar el panorama púnico de Ibiza (Tarradell y Font 1975) respecto de las costas catalanas (Maluquer 1969) practicamos igualmente excavaciones en Vinarragell (Burriana, Castellón) en colaboración con Norberto Mesado, esta vez con resultados que a la postre fueron pioneros en la comprensión de las relaciones fenicias occidentales en el Nordeste de la Península Ibérica (Arteaga y otros 1978).

Como apuntamos en su momento (Arteaga y Serna 1974: 49-56) dentro del cauce idealista del positivismo se estaba construyendo un esquema evolutivo (no hay que olvidarlo) que en atención al paradigma grecorromano miraba con agrado una supuesta "perduración" de las culturas prehistóricas de El Argar y del Bronce Valenciano (Pla 1959: 128-133; Fletcher y otros 1965 y 1969; Llobregat 1969; 1972; Tarradell 1962; mantenida incluso en Gil-Mascarell y Aranegui 1981: 31) llegando la misma hasta los tiempos de la fundación de Ampurias y después. Por lo que nada extraña que apoyados en las estratificaciones observadas en Torre del Mar (Schubart y otros 1969), en el Cerro del Real de Galera (Pellicer y Schüle 1962 y 1966), en Los Saladares (Arteaga y Serna 1973) y en Vinarragell (Arteaga y Mesado 1979), y utilizando las mismas armas comparativas (las razones estratigráficas de la época), hubiéramos edificado las evidencias arqueológicas de una contradicción: por una parte negadora del esquema entonces propuesto de cara al origen de la Cultura Ibérica, y por otra mostrativa del proceso diacrónico que se mantiene (que nosotros sepamos) hasta nuestros días (Ruiz y Molinos 1992). Lo que discutimos ahora no es el normativismo de la cultura, sino la dialéctica del proceso histórico-social, en base a reciclar el superable esquema de los "horizontes" del positivismo estratigráfico.

Dados los parámetros básicamente positivistas y culturalistas, dentro de los cuales se planteaban las discusiones en las publicaciones, congresos y coloquios de los años setenta, los argumentos esgrimidos sobre el origen de la manifestación orientalizante tartesia (AA. VV. 1969) y sobre el origen del Mundo Ibérico (AA. VV. 1976-78) -valga aquí nuestra autocrítica- se fueron polarizando hacia los citados supuestos normativistas: expresando los mecanismos culturizantes en horizontes referidos a los paradigmas dependientes de la colonización; cuando paradójicamente desde la parte indígena intentábamos desentrañar un proceso histórico relativo a la formación del poblamiento (Arteaga 1976-1978). No habíamos caído todavía por nuestra parte en cuenta, de que, para desentrañar este proceso, hay que hacerlo comenzando desde el análisis de la formación de la sociedad, y no prioritariamente desde el estudio concerniente a la manifestación de la cultura.

Mientras estábamos inmersos en el debate normativista de "la iberización" los trabajos arqueológicos en las costas meridionales de Andalucía continuaban aportando una copiosa cantidad de información, que a punto estaba de hacer "pendular" la negación del llamado "impacto griego", hacia una afirmación extrema del llamado "impacto fenopúnico". 
Manuel Fernández Miranda, a quien rendimos aquí un sentido recuerdo, había comenzado por entonces en colaboración con Luis Caballero Zoreda sus excavaciones en la zona púnica-romana del Cerro de Montecristo de Adra (Fernández Miranda y Caballero 1975). Y las excavaciones de Malaka habían sido retomadas por Isserlin (1975). También se hicieron destacadas, en aquella misma década, las excavaciones practicadas en otros yacimientos fenicios y púnicos, tales como: Cerro del Alarcón (Schubart, Niemeyer y Lindemann 1972), Jardín (Schubart 1979), Cerro del Mar (Arteaga 1979), Toscanos (Niemeyer 1979), Chorreras (Aubet 1974; Aubet y otros 1979), Morro de Mezquitilla (Schubart y Niemeyer 1976; Schubart 1979), así como los hallazgos del Cerro del Prado (Pellicer y otros 1973) y de la sorprendente necrópolis de Trayamar (Schubart y Niemeyer 1976).

Si bien no faltaron estudios especializados fundamentados en criterios socioeconómicos y sociopolíticos, referidos a los fenicios occidentales, puede decirse que los mismos pasaron casi desapercibidos; por lo que siguieron prevaleciendo aquellos versados en las citadas tónicas culturalistas.

Desde una panorámica mediterránea, era la interpretación de una visión comercial la que se estaba imponiendo, como explicación dominante, respecto de la presencia fenicia en Occidente (Moscati 1972). Afirmándose que en la misma proyección comercial tanto los fenicios como los cartagineses serían "portadores" de una misma "civilización". La civilización que desde Oriente, de una manera benefactora para el progreso de los pueblos autóctonos, "irradiarían" los semitas hacia Occidente (Moscati 1972). Los asentamientos localizados en las costas andaluzas funcionarían como escalas de navegación, indicativas del prevalente carácter comercial de la colonización, que enfocada a través de Gadir tendría la finalidad de conectar con Tartessos.

La "irradiación" cultural semita supondría el reflejo del establecimiento de unas funcionalidades coloniales articuladas para tales fines comerciales (Acquaro 1978). Lo que, en suma, conformaría una dinámica entre las fundaciones coloniales, para controlar los territorios costeros y las rutas de penetración, y las fundaciones de emporia, para la organización del tráfico comercial propiamente dicho (Bondí 1978 y 1983). Con argumentos evidentemente normativistas, se interpretaba que las "irradiaciones semitas" difundirían los rasgos civilizadores orientales, que influirían en los cambios culturales observados en las poblaciones indígenas (Bondí 1978; Bisi 1983).

Frente a las argumentaciones eminentemente comerciales, tampoco dejaron de pronunciarse opiniones contrarias. Como la expresada por el británico Charles R. Whittaker, quien aparte de negar la existencia de un monopolio mercantil controlado por Tiro (Whittaker 1974) afirmaba, como había señalado Jorge Bonsor en sus Colonies agricoles pré-romaines de la Vallée du Bétis (1899), que la diáspora fenicia habría tenido en el Extremo Occidente una finalidad crucial: la búsqueda de tierras agrícolas para su explotación.

La incrementación de los efectivos coloniales, necesitados de tierras, por las presiones asirias en Oriente, correría pareja en Occidente con una asimilación creciente de elementos indígenas, que desde el principio habrían prestado su fuerza de trabajo a los colonizadores. La fundación de Cádiz, por consiguiente, iba a estar determinada por el interés que los fenicios tenían en la captación de las fértiles tierras del Valle del Guadalquivir, introduciéndose allí los "efectivos" agrícolas determinadores de una colonización territorial. La división del trabajo, entre los dominadores fenicios y los indígenas socialmente inferiores, habría generado el desarrollo de un proceso de dominación marcado por la desigualdad (Whittaker 1974).

Otra visión referente a la colonización en las costas meridionales de Andalucía fue la ofrecida por Susan Frankenstein, para quien los asentamientos aquí conocidos tendrían funcionalidades complementarias, indistintamente dedicadas a la producción y al comercio. La estrategia de la colonización, cifrada en el comercio y en el monopolio mercantil de los recursos peninsulares (destacando sobremanera el 
interés por la plata) se promovería desde Oriente en razón del sistema tributario dentro del cual se encontraban inmersos los fenicios, respecto de la dominación asiria (Frankenstein 1979).

No faltaron también en la citada década trabajos referidos a las condiciones del medio explotado por las colonias fenicias occidentales, en una línea ambientalista. Desde perspectivas puramente descriptivas, en buena parte inspiradas en las corografías mediterráneas de Ferdinan Braudel, se conoce el estudio publicado por Brigitte Warning-Treumann, intentando mostrar desde un paisaje presentista la importancia de los recursos del medio respecto de la colonización. Asumiendo un enfoque rayano con el debate determinista y ambientalista de las teorías adaptativas, la autora quiere mostrar cómo el mismo entorno geográfico pudo haber sido explotado de una manera similar por los fenicios, quedando los suelos, la flora y la fauna desde entonces afectados por la intervención humana (Warning-Treumann 1978). La aludida transformación del medio, sin embargo, no se tiene en cuenta como un proceso cambiante, en tanto que paradójicamente son los referentes del paisaje actual los que la autora traslada a los tiempos coloniales.

El estudio resultaba, en cualquier caso, novedoso, sobre todo teniendo en cuenta que la historiografía especializada se encontraba todavía dominada por la triada metodológica del difusionismo, evolucionismo y positivismo, al servicio del Historicismo Cultural.

\section{VII.- LA ECLOSIÓN TEÓRICA DE LOS AÑOS OCHENTA}

La historiografía referida al estudio de los fenicios y púnicos en Occidente, durante los años ochenta, comporta la evidencia de una apertura crítica anteriormente inexistente: es la década de la eclosión teórica, en España y en Andalucía.

Cuando todavía se encontraba en una franca progresión el debate con el normativismo, sobre la culturización de las poblaciones indígenas, por parte de las influencias coloniales, las relaciones entre fenopúnicos y tartesio-iberos (AA. VV. 1987) empezaron a verse cuestionadas a tenor de unos parámetros conceptualmente distintos. Las teorías sociales, entre otras, comenzaban a abrirse camino.

La novedad de aquella década, por consiguiente, radica en que las numerosas excavaciones practicadas en Andalucía, formando parte de significados "Proyectos de Investigación" (Anuario Arqueológico de Andalucía 1985-1990) pudieron ser aquilatadas a la luz de distintos enfoques referidos al funcionalismo, al estructuralismo, al materialismo cultural y al materialismo histórico.

Esta apertura crítica estaba conectada, por supuesto, con el nuevo estado del debate teórico que entonces venía suscitándose en España (AA. VV., Coloquio de Soria 1981; AA. VV., Coloquios de Teruel 19841986). No dándose su puesta al día en Andalucía hasta después de 1984: año de la convocatoria organizada con motivo de la celebración del Homenaje a Luis Siret, en Cuevas del Almanzora, Almería (AA. VV. 1986).

Los resultados más trascendentales, que nosotros ahora valoramos, fueron aquellos que a partir de las discusiones planteadas en el Homenaje, en torno a la actualización de las distintas parcelas investigativas de la Arqueología Andaluza (no publicadas en las actas) acusaron el cambio radical que se estaba promoviendo: dadas las distintas alternativas teóricas y metodológicas que entonces quedaron contrastadas, con aquellas que antes venían conociendo un predicamento casi en exclusiva (AA. VV. 1986).

La nueva situación, también cabe remarcarlo, provocaría las reacciones teóricas de quienes sin abandonar los supuestos conceptuales de las suyas, de una manera paradójica, continuarían afirmando que "las teorías no sirven para nada" (Pellicer 1995). 
Muchas posturas, ideológicamente recalcitrantes, que primero actuaban ocultas bajo sus métodos aparentemente inocentes, salieron de pronto a la luz. Para con la cara descubierta, rechazar las propuestas formuladas por otros colegas, más proclives a las nuevas perspectivas del diálogo científico. Unos y otros, cerraron y siguen cerrando filas.

Mientras que los "aperturistas" consideran que el debate de las diversas alternativas teóricas resulta saludable para el avance de la arqueología al servicio de la Historia, para los "conservaduristas" dicho debate resulta innecesario: afianzados como están en la renovación de los paradigmas creados a lo largo de cien años, al servicio del Historicismo Cultural.

Como era de esperar, tampoco faltaron, entre los primeros y los segundos, los investigadores que sin "declarar" una toma de postura consecuente continuaran, como una mayoría silenciosa, incrementando con sus excavaciones los datos documentales, que de una manera incuestionable pasaban a formar parte de los posmodernos acopios informáticos; que tanto interesan al neo-positivismo.

En esta coyuntura, no pocos han sido los arqueólogos que asumiendo la metatécnia de una supuesta neutralidad científica, hayan tomado una postura inequívoca detrás del parapeto de sus ordenadores. La mayoría de las veces, no para cuestionar con estos medios tan epatantes unas realidades históricas (ontológicamente vistas) sino para proyectar sus modelos y simulaciones como realidades virtuales.

Aparte de las diferentes posturas teóricas, que como acabamos de exponer se fueron decantando, a nivel informativo cabe reseñar que entre 1980 y 1990 aparecieron publicados en relación con los fenicios, tartesios y púnicos en Occidente nuevos trabajos de síntesis (Niemeyer 1982b; Bisi 1983; Koch 1974; Schubart y Arteaga 1986; Del Olmo y Aubet 1986; Arteaga 1987; Aubet 1987; Bondí 1988; Barceló 1988; Aubet 1989; Schubart y Arteaga 1990), a los que tienen que añadirse además de las actas de coloquios tales como los de Huelva (AA. VV. 1980) y de Colonia (Niemeyer 1982a), los informes preliminares de incontables actuaciones sistemáticas y de urgencia, que se promovieron contando con las considerables subvenciones económicas libradas, a partir de 1985, por la Dirección General de Bienes Culturales de la Junta de Andalucía (AA. VV., Anuario Arqueológico de Andalucía 1985-1990).

La política cultural desarrollada por la Junta de Andalucía, en materia de Arqueología Urbana ha surtido efectos notables en Gadir, Malaka, Sexi, Abdera y Baria. Unos asentamientos que siguen siendo, a pesar de todo, muy mal conocidos: por hallarse como hemos dicho cubiertos por las aglomeraciones ciudadanas actuales.

No obstante, hemos de enfatizar aquí que los resultados arqueológicos obtenidos en las excavaciones practicadas hasta mediados de los años ochenta, en las costas malagueñas, granadinas y almerienses, han sido para nosotros evidenciadores de que la colonización fenicia alrededor del Círculo del Estrecho (Tiro con Gadir) formaba parte de una organización de ESTADO. Y de esta manera, en 1985, lo expusimos en las I Jornadas sobre el Mundo Ibérico, celebradas en Jaén (Arteaga 1987: 207-208). En efecto, gracias a las prospecciones geoarqueológicas que nosotros mismos realizamos, también a partir de 1985, en colaboración con el geólogo Gerd Hoffmann, en el marco investigativo del "Proyecto Costa", sobre el cual volveremos más adelante (Arteaga y otros 1985 y 1988) pudimos reconstruir las antiguas líneas costeras y observar la manera en que los fenicios asentados en los entornos marítimos de Malaka, Sexi, Abdera, Baria, y otras zonas localizadas en las costas mediterráneas de Andalucía, habían llevado a cabo la ordenación de sus territorios respectivos. A todas luces, de acuerdo con unos patrones de asentamiento muy diferentes a los griegos, que muchos autores venían tomando como referentes al hablar de tales establecimientos coloniales. Siendo por el contrario los observados por nosotros más equiparables con los territorios costeros de Tiro, Cartago y Gadir, era evidente que aquellos patrones se repetían en los círculos productivos organizados en torno a los principales núcleos fenicios occidentales que acabamos de citar. Las planificaciones de tales ordenaciones territoriales, contrastadas en relación 
con una vinculación de dependencia económico-social y política respecto del Estado tirio, alrededor del 800 a. C., fueron las que nos afirmaron en la convicción de que la fundación de Gadir, y consecuentemente la explotación de los territorios coloniales en torno a Malaka, Sexi, Abdera, etc., habían obedecido a unas empresas estatalizadas. Por lo que nosotros, en contra de no pocas interpretaciones opuestas, nos sumamos a quienes opinan en atención a las estructuras económico-sociales propias de las sociedades fenicias occidentales y tartesias, que de ninguna manera se puede negar aquí la existencia del Estado. Cabiendo discutir, en todo caso, su definición concreta, en torno al Círculo del Estrecho.

Dicho lo anterior, hemos de volver a retomar el hilo de nuestra reseña, para intercalar aunque sea de pasada una somera referencia sobre el copioso registro bibliográfico que se ha producido en la década citada, permitiendo constatar las importantes actividades arqueológicas realizadas entre Tarifa (Martín Bueno 1988; Fernández Barbará 1989) y Villaricos (Suárez 1987 y 1988). Resultan destacables las consignadas en relación con el Cerro del Prado (Ulrreich y otros 1990), Casa de Montilla (Schubart 1990), Cerro del Castillo de Fuengirola (Arteaga y Hoffmann 1990), Cerro del Villar de Guadalhorce (Aubet y Carulla 1986), Málaga Ciudad (Gran y Alexandropoulos 1987; Gran 1988), Cerro del Peñón (Niemeyer y otros 1988), Alarcón (Schubart 1988), Manganeto (Arteaga 1985: 186), Puerto de Toscanos (Schulz 1988; Arteaga 1988), Cerro del Mar (Arteaga 1985); Almuñécar Ciudad (Molina 1984 y 1986), Necrópolis de Puente de Noy (Molina y otros 1982), Cerro de Montecristo de Adra (Suárez y otros 1989; López Castro y otros 1991) y Cabecico de Parra (López Castro y otros 1988).

Entre otras aportaciones bibliográficas aparecidas, cabe destacar la síntesis ofrecida por M. E. Aubet, en su obra titulada Tiro y las colonias fenicias occidentales, en la cual los asentamientos de la costa mediterránea andaluza quedan integrados en un modelo de diáspora comercial, dependiente de la organización estatal metropolitana, a través de la capitalidad occidental localizada en Gadir. Se destaca la importancia que para la administración tiria tenía la institución política económica y religiosa del templo de Melkart, como garante de la intervención de la monarquía en toda la actividad comercial (Aubet 1987).

En un análisis minucioso del proceso diacrónico de la colonización fenicia occidental, la autora nos resume los conocimientos relativos a la información bibliográfica existente, por lo que sus referencias y sugerentes comentarios constituyen un hito historiográfico a tener siempre en cuenta, en el futuro venidero de la investigación (Aubet 1987). En vista de que la obra ha sido reeditada poco después (Aubet 1994) volveremos nuevamente sobre ella, en su momento oportuno.

Otra aportación importante, la encontramos en las propuestas hipotéticas formuladas por Jaime Alvar y Carlos González Wagner, retomando por su parte las ideas de C. R. Whittaker, anteriormente reseñadas (Whittaker 1974). Utilizando modelos antropológicos entroncados con el Materialismo Cultural; y en gran medida con el Neoevolucionismo norteamericano (sobre las sociedades tribales y aldeanas) estos autores defienden la existencia de una colonización agrícola llevada a cabo por los fenicios en el Valle del Guadalquivir (González Wagner 1983; Alvar y González Wagner 1989).

La colonización, aparte de las causas comerciales y políticas, tendría para estos colegas también otros impulsos, ecológicos y demográficos, que en Oriente incidirían en las limitaciones de los recursos madereros, y en las tierras agotadas por la erosión. Por lo que sumadas a las presiones de otros pueblos vecinos, los fenicios tendrían causas suficientes para verse obligados a buscar nuevas fuentes de aprovisionamiento, y sobre todo tierras para darle salida a sus excedentes demográficos (Alvar y González Wagner 1989).

Según opinan, la ocupación del Valle del Guadalquivir sería llevada a cabo por grupos familiares de colonos, que estarían sometidos a las ordenaciones catastrales tributarias de Gadir, y explotarían las nuevas tierras utilizando un régimen de dependencia servil, aprovechando la mano de obra indígena. 
La idea del grupo familiar, también en la estructuración de una sociedad aldeana, les lleva a extrapolar de los antropólogos neo-evolucionistas (González Wagner 1990 y 1992) un supuesto modo de producción doméstico, que en el Valle del Guadalquivir respecto de la formación social tartesia nos parece improbable: frente a lo que aducen quienes apoyan estos criterios (Carrilero 1992: 128-129).

Aparte de que, diacrónicamente, los citados autores no elevan el esquema neo-evolucionista a la época que le corresponde, para discutir también en la Baja Andalucía y en el Valle del Guadalquivir el problema relativo a la formación de una sociedad clasista inicial y de un Estado prístino (Arteaga y Roos 1992) en momentos anteriores al "horizonte espacio temporal" de la sociedad tartesia (Arteaga y Roos 1995), entran por su parte en una contradicción mayor cuando quieren afirmar dichos planteamientos sin apenas contrastarlos con los pertinentes registros arqueológicos (Arteaga 1985: 284 y lám. V), a los que suelen aludir en abstracto, como si no existieran diferencias entre unos y otros asentamientos, y todos por igual fueran unas simples aldeas. Otra contradicción radica en que una vez asumido el modelo antropológico neo-evolucionista, para la definición sincrónica de unos modos de vida que no coinciden con el modo de producción de las sociedades contrastadas, pasan al mismo tiempo, al orientarse para realizar dicha contrastación, a tomar su apoyo en el modelo comparativo referente a la colonización griega; que ni siquiera sirve para explicar lo que observamos actualmente los arqueólogos respecto de los patrones de asentamiento en los territorios fenicios occidentales (Arteaga 1993-1994).

Aunque el citado modelo interpretativo plantea una relación desigual establecida entre colonizadores e indígenas, no esclarece de una manera convincente cuáles eran las relaciones de propiedad respecto de las tierras ocupadas, ni las desigualdades estructurales propias de la formación económico-social tartesia: dando por sentado que esta última comportaba todavía una organización tribal, aldeana (González Wagner 1992: 90-93; Carrilero 1992: 128-129); para nosotros superada en tiempos precedentes (Arteaga y Roos 1992 y 1995).

No obstante, la propuesta de Alvar y González Wagner resulta sumamente interesante, por el debate que suscita: y no dudamos que se habrá de retomar más de una vez, incluso por los mismos autores, dadas las matizaciones que los registros arqueológicos en el Valle y en la Cuenca del Guadalquivir permiten establecer, respecto de la sociedad tartesia; no tan aldeana como ellos afirman; apegados al esquema neoevolucionista que intentan aplicar, para trasladando al territorio en cuestión la idea de la progresión entre la tribu y la jefatura conectar el desarrollo tartesio con el paradigma clásico grecorromano, según el cual anteriormente no pudo existir en Occidente ninguna sociedad clasista, ni por lo tanto ninguna sociopolítica de Estado (Plácido y otros 1991). Se conjuntan así dos paradigmas científicos, para intentar centrar entre ambos la realidad histórica tartesia, al lado de la relación desigual con los colonizadores orientales. Se propugna el paradigma antropológico neo-evolucionista de la tribu-jefatura y Estado; y para acceder a éste último se antepone sin embargo la condición del citado paradigma grecorromano. Por lo que el interludio, entre el Bronce Final y los Turdetanos, como mucho se contempla en los términos de la jerarquización de una sociedad tribal: la jefatura (González Wagner 1992: 100).

Aunque las asimilaciones de elementos indígenas en el mundo colonial fenicio, como las propias de elementos fenicios en el mundo tartesio, a todas luces nos parecen probables: pensamos por nuestra parte que las relaciones desiguales eran consustanciales con las estructuras clasistas, dominantes, respectivamente en ambas sociedades.

Desde esta perspectiva, el parangón entre una estructura oligárquica, creciente en relación con los fenicios occidentales asentados en las costas periféricas del mundo tartesio, y una estructura aristocrática, afirmada en los territorios del hinterland, no permite que planteemos los problemas relativos a la utilización de la mano de obra servil de una manera unilateral, ni de una forma abstracta. Ya que tampoco sería 
igual la condición social de los artesanos, de los campesinos, y de los esclavos, dependiendo del proceso de trabajo en que se vieran integrados.

Es por lo tanto preciso, como hemos dicho, determinar en los territorios tartesios, como en los fenicios, en manos de quiénes estaba la propiedad de las tierras, aguas, ganados y minas, así como la de otros medios productivos. Para una vez planteadas cuáles eran las relaciones sociales de producción, apoyadas en unas concretas relaciones de propiedad, poder esclarecer la mediación clasista de las elites fenicias y tartesias, definiendo las condiciones sociales según las cuales los trabajadores foráneos e indígenas podían quedar adscritos, en distintos grados de desigual explotación, a las diversas parcelas del proceso productivo: tanto en lo tocante a los núcleos mayores de poblamiento, como en lo tocante a las faenas referidas a los sectores campesinos, ganaderos, mineros y marítimos. Sin definir la posición que los hombres, respecto de otros hombres, ocupan en un sistema de producción históricamente determinado, por las relaciones en que se encuentran con respecto a la propiedad de los medios de producción, difícilmente se pueden explicar las relaciones de desigualdad que se concretan en la organización social del trabajo, ni las consiguientes relaciones de explotación que se expresan en el modo y proporción en que unos y otros reciben la parte de la producción social de que disponen. Por lo que el concepto de desigualdad, si no se explicita en estos términos, degenera en una expresión ambigua, puramente especulativa.

Por otra parte, la complejidad poblacional que nosotros objetamos, frente a la pretendida sociedad aldeana, comporta una diversificación sociopolítica y por lo tanto ordenadora de muy amplios territorios, que debe ser vista contrastando las características de los grandes núcleos ubicados a lo largo del Guadalquivir, respecto de los poblados localizados en la Cuenca, y en otras tierras "periféricas", situadas entre las colonias costeras y el hinterland. Para en justa comparación con otros centros tartesios avecinados a la costa, dirimir entre lo urbano y lo rural el papel de las pequeñas aldeas (Arteaga y Roos 1992).

En este sentido, repetimos, no puede ser igual la valoración sociohistórica de una ordenación territorial aldeana, que la correspondiente a una más compleja ordenación territorial con aldeas (Arteaga y Roos 1992 y 1995: 211; Arteaga 1993-1994: 28).

En nuestra opinión, durante el período orientalizante, más que de "periferias" cabe hablar de "fronteras territoriales". Valorando desde los centros tartesios, localizados en las costas atlánticas y en el Valle del Guadalquivir, sus delimitaciones fronterizas hacia los cuatro puntos cardinales. Y no solamente en atención a las periferias territoriales fenicias, ubicadas hacia la fachada litoral atlánticomediterránea. Por lo que dependiendo de la relectura de las evidencias arqueológicas (que se niegan sin realizar ninguna contrastación) y del análisis de las relaciones sociales de producción que los fenicios y tartesios consolidaron mediante las respectivas ordenaciones políticas en tan amplios territorios, esperamos que se retome la problemática relativa a la existencia del Estado: que los citados colegas y sus seguidores rechazan, declaradamente, sin valorar cuál era entonces al respecto (cuando menos) el papel sociopolítico que Gadir desempeñaba en Occidente (Arteaga 1993-1994).

En cualquier caso, cabe enfatizar que el nivel actual del debate planteado respecto de los fenicios y tartesios (Alvar y Blázquez 1993) al abordarse desde perspectivas socioeconómicas y sociopolíticas (López Castro 1990: 11-79) supera con creces las miras del debate culturalista, dominante hasta nuestros días.

Todavía en la década de los años ochenta, por último, nos quedan por mencionar los resultados que en colaboración con H. Schubart, H. D. Schulz y G. Hoffmann, nosotros mismos hemos obtenido en el desarrollo investigativo del "Proyecto Costa". Un programa geoarqueológico destinado a la reconstrucción del proceso natural y del proceso histórico, que en una contrastación dialéctica nos explica la transformación del medio litoral de Andalucía: y el estado en que se hallaban las antiguas 
líneas costeras, cuando los fenicios establecieron en ellas sus asentamientos y puertos (Arteaga y otros 1985 y 1988).

Estando los antecedentes más inmediatos (Warning-Treumann 1978) basados en corografías presentistas, era muy evidente que el dominio explicativo de la morfogénesis del litoral mediterráneo de Andalucía hasta los años ochenta no se encontraba en manos de los arqueólogos. Pero a niveles más generales, las teorías relativas al ambientalismo, en la perspectiva de la Geografía Física (Menanteau 1982) ya venían desarrollando programas interdisciplinarios: mostrativos de que una estrecha colaboración entre los geólogos, geógrafos y arqueólogos era sumamente factible, y para la discusión de los efectos antrópicos, respecto de los procesos geomorfológicos en los tiempos históricos, absolutamente necesaria.

No otras eran, por entonces, las proyecciones que se impulsaban desde la Escuela de Cambridge, y desde la Escuela de Chicago: bien fuera siguiendo los postulados de C. Vita-Finzi (1969, 1972 y 1976), bien fuera siguiendo los encabezados por K. Butzer (1972, 1974 y 1982).

Los presupuestos teóricos y metodológicos de la Escuela de Cambridge, se definían en una Arqueoecología. Es decir, en una arqueología ambiental, asumiendo una interpretación eco-histórica en la que el análisis antrópico se basaba en la ecuación abstracta hombre-medio.

La geoarqueología, en la versión de la Escuela de Chicago, asumía una postura más contextualista, pero valorando lo antrópico desde la teoría de la adaptación y de la adaptabilidad (Butzer 1982).

Nuestra postura, frente a los conceptos ambientalistas y adaptativos, iba a contemplar en el desarrollo investigativo del Proyecto Costa (Arteaga y otros 1985 y 1988) una visión del concepto antrópico nada pasiva, mucho más contradictoria, en consonancia con la valoración de su contenido social. Se trataba, por lo tanto, de una concepción menos ecologizante del hombre. Desde la perspectiva teórica de una Arqueología Social no podíamos entender los efectos antrópicos como algo neutro, identificados con el hombre en abstracto: sino más bien como efectos cuestionables a partir de las relaciones sociales que los hombres establecen con los hombres, para una vez organizados pasar a establecer relaciones sociales con la Naturaleza. No en términos ecológicos, precisamente, sino en términos de la explotación de sus recursos.

Los territorios socialmente explotados por los fenicios, en las costas mediterráneas de Andalucía, fueron estudiados a partir de los fundamentos teóricos y metodológicos ensayados entre 1982 y 1984 , en el litoral de la Axarquía malagueña (Arteaga 1988: 127-141; Schulz 1988: 142-154) quedando sus resultados consignados en los propios del "Proyecto Geoarqueológico" practicado a partir de 1985 (Hoffmann 1988; Arteaga y Hoffmann 1990).

Mediante los trabajos geoarqueológicos del "Proyecto Costa", en definitiva, hemos podido explicitar el proceso histórico dentro del cual hasta el Bronce Final (1000-800 a. C.) el estado de las colmataciones sedimentarias, causadas por unos efectos erosivos que venían siendo coadyuvados por actividades productivas humanas (deforestaciones, usos y abusos de los suelos: agriculturas, ganaderías, minerías,...) se encontraba mucho más avanzado en los ríos Almanzora, Antas, Aguas y Andarax, que en las colmataciones observadas en los ríos del entorno de Sierra Nevada y de Gibraltar. Por lo que la relación de explotación de la sociedad-medio se traducía hasta comienzos del último milenio más incisivamente transformadora de la Naturaleza en los territorios del Sudeste, y más atenuada entre el río Grande de Adra y Tarifa.

Hacia el 800-750 a. C., por consiguiente, los fenicios emplazaron sus asentamientos coloniales en las costas periféricas del mundo tartesio, conociendo en el litoral del Mediodía unas condiciones naturales relativamente mejor conservadas, en comparación con las otras líneas de costa que también abarcaron hacia el más degradado medio del Sudeste. Pero este relativo estado de conservación iba a mantenerse muy poco tiempo. Ya que a partir del siglo VIII a. C., en torno a las costas meridionales la colmatación se dispara, hasta niveles antes desconocidos (Arteaga 1988; Schulz 1988; Hoffmann 1988). Siendo evidente 
que el poblamiento fenicio llegaría a propiciar una fuerte presión antrópica en aquellos medios costeros, que nosotros identificamos con la implantación repentina de la tecnología del hierro, la introducción de unos nuevos patrones de vida urbana, y sobre todo con la instauración de un modo productivo hasta entonces desconocido en los citados territorios. Toda la periferia costera del mundo tartesio se encontraría ordenada territorialmente, para su explotación, desde los nuevos centros poblacionales del mundo colonial: estructurando una sociopolítica estatal, adscrita a Gadir, como centro capital de la soberanía tiria en Occidente (Aubet 1987 y 1994; Arteaga 1993-1994).

Por lo que la instauración del urbanismo fenicio, y la tecnología del hierro, suponen con la consolidación de un nuevo modo productivo la incidencia sociohistórica de una transformación del medio costero, que hemos de referir durante los siglos VIII-VII a. C. al "paisaje colonial". La explotación rigurosa de las riquezas del mar, iba a correr pareja con la explotación intensa de los suelos en los valles y piedemontes. Los cultivos en terrazas, con fines productivos industriales y mercantiles (vino, aceite) permitieron desarrollar actividades comerciales solamente comparables en rentabilidad con las famosas salazones, y con el tráfico de otras materias primas, entre las que se hallaban los metales. La minería y la metalurgia, las alfarerías especializadas, como los hornos domésticos y los industriales, al lado de las necesidades madereras para fines constructivos en los asentamientos, instakaciones portuarias y los barcos, deben ser valoradas en atención a las grandes acometidas antrópicas que hubo de sufrir el medio natural, aparte de las citadas agriculturas y ganaderías que los fenicios practicaron, en detrimento de la cubierta vegetal y desmantelamiento de muchas masas forestales.

Hacia comienzos del siglo VI a. C., los resultados geoarqueológicos del "Proyecto Costa" nos ponen claramente en evidencia del estado de colmatación acelerada en que se hallaban las ensenadas y bahías marítimas, cuando se sabe que las costas del litoral mediterráneo de Andalucía, frecuentadas por los griegos foceos (fundadores de Ampurias), pudieron quedar descritas en los periplos que entre otros se significaron en el recuerdo de la "Ora Maritima" de Rufo Festo Avieno (Arteaga y Roos 1995).

Una prolongada y extensiva explotación del mismo territorio costero, ocupado durante el período colonial, es la que puede analizarse a partir de finales del siglo VI a. C. como propia del mundo púnico occidental (Arteaga 1990): ahora por parte de los centros poblados que se fueron nuclearizando como urbanos en Malaka, Sexi, Abdera y Baria, entre otros. Hasta convertirse en verdaderas "poleis" (Arteaga 1990 y 1993-1994).

Las colmataciones sedimentarias, que continuaron haciendo cambiar las antiguas líneas costeras en todo el litoral, a tenor de la geoarqueología del "Proyecto Costa", resultan sumamente indicativas de la realidad sociohistórica que se afianza en dichos territorios, con el consiguiente peso antrópico que nosotros identificamos con el desarrollo de un nuevo modo productivo, incidiendo sin mengua en la transformación del paisaje prerromano.

La ordenación territorial, de los núcleos urbanos y de los medios rurales, antes de la Segunda Guerra púnica, comporta la plasmación socio-económica y socio-política de un nuevo modelo de paisaje antropizado, que en la relación dialéctica del proceso histórico se puede vincular con el desarrollo de la "polis" en Occidente.

Es el sistema productivo propio de la "polis", con sus parcelamientos rurales, el que durante los tiempos prerromanos se consolida en las castigadas tierras costeras de Andalucía. Por lo que las transformaciones operadas en el medio litoral, con la explotación de los recursos de la tierra y del mar, a niveles explosivamente industriales, fueron las que seguidamente se integraron en el orbe romano; aunque no quedaran debidamente valoradas desde la proyección histórica de su proceso, por parte de los escritores grecolatinos. La síntesis de todo lo antes dicho, cuando menos, podemos irla perfilando 
mediante la contrastación de los resultados geomorfológicos del "Proyecto Costa", con las referencias textuales de los tiempos relativos a la Geografía de Estrabón (Arteaga y Roos 1995).

Como bien apuntamos en su momento (Arteaga 1981 y 1985) el proceso histórico prerromano no significaría otra cosa que la integración del modo productivo fenicio occidental en la esfera económicosocial y política del Imperio de Roma: por lo que la explotación constitutiva de la transición tardopúnica, referida a la mal concebida "romanización", no se puede entender sin las relaciones productivas que continuaban capitalizando en Occidente las clases sociales dominantes, en cuyas manos estaban las propiedades territoriales que los catastros romanos reestructuraron.

En esta perspectiva sociohistórica, se entiende la asimilación de los territorios productivos del litoral mediterráneo que nos ocupa, por parte de Roma, y al mismo tiempo la intensificación del sistema de explotación que continuaría ejerciéndose sobre aquellos mismos medios litorales: acelerándose los procesos erosivos que hacia la época de Augusto habían hecho cambiar de nuevo la fisonomía de las líneas costeras (Arteaga y Roos 1995).

\section{VIII.- LAS TEORÍAS SOCIALES Y LA CRISIS DEL HISTORICISMO CULTURAL}

Durante los últimos cinco años transcurridos de la década de los noventa el número de las excavaciones arqueológicas en las costas mediterráneas de Andalucía ha disminuido de una manera considerable. Ello se debe al receso en que ahora se mantienen los proyectos sistemáticos autorizados por la Dirección General de Bienes Culturales de la Consejería de Cultura de la Junta de Andalucía; con motivo de la elaboración de las memorias sobre las actividades realizadas entre 1985 y 1991.

Se pueden mencionar, no obstante, las excavaciones practicadas en el Cerro del Villar de Guadalhorce (Aubet 1993 y 1994), el Cerro del Castillo de Fuengirola (Hiraldo y Riñones 1991; Hiraldo y otros 1992), la Necrópolis de Lagos (Aubet y otros 1991), el Islote de Salobreña (Arteaga y otros 1992), Villaricos (Alcaraz 1991) y Málaga (Recio 1990).

Más reveladores del estado actual de la investigación, vienen siendo los trabajos de síntesis, que han continuado apareciendo, como producto de seminarios, coloquios y aportaciones individuales (Gehrig y Niemeyer 1990; Blázquez 1992; López Castro y Carrilero 1992; Alvar y Blázquez 1993; Arteaga 1993-1994; Beltrán y Gascó 1994 y 1995; Aubet 1994; López Castro 1995; Ramón 1995), ofreciendo en su conjunto el mejor balance que podamos referir, para significar el cambio experimentado por los estudios fenicios y púnicos en España, en las fechas inmediatas a la celebración del IV CONGRESO INTERNACIONAL DE CÁDIZ.

En efecto, nos encontramos ante la evidencia de un salto cualitativo, motivado a nuestro entender por la crisis del Historicismo Cultural, ante la apertura proporcionada por la eclosión teórica de los años ochenta. Una apertura crítica y constructiva que en el pasado lustro no ha dejado de quedar cada vez más abocada en la explicitación del proceso histórico atlántico-mediterráneo, tanto en las expectativas de la sociedad fenicia occidental como en las concernientes a la sociedad tartesia.

Las teorías sociales, en definitiva, han logrado consolidarse como alternativas a las teorías culturalistas. $\mathrm{Y}$ en esta nueva circunstancia, radica el cambio operado.

En la situación actual del debate suscitado, los mantenedores acérrimos de las consabidas interpretaciones difusionistas, evolucionistas y positivistas no han cesado de mostrar su reacción. Mientras que, por otra parte, quienes propugnan la prioridad analítica de las categorías socioeconómicas, sociopolíticas y socioculturales para acceder a la reconstrucción de una historia total, puestos a ganar una mayor coherencia crítica ante aquéllos, no han tenido otro remedio que denotar claramente las posturas 
teóricas que asumen. Con lo cual estas decididas tomas de posturas han dado termino al dominio imperante que desde hace cien años venía teniendo el Historicismo Cultural.

En el contexto sociohistórico de esta última consecuencia, que vemos todavía palpitante en la encuesta que podemos realizar a tenor de las comunicaciones presentadas en el CONGRESO INTERNACIONAL DE CÁDIZ, nosotros estamos convencidos de que al lado de las distintas reacciones provocadas por las Teorías Sociales, la historiografía arqueológica de las próximas décadas habrá de calibrar en su debido merecimiento las de aquellos colegas que de espaldas a la realidad enarbolan encarecidas "defensas" del difusionismo, evolucionismo y positivismo, para justificar sus propios idealismos historicistas, en algún caso mediante la expresión de manifiestos extemporáneos (Pellicer 1995).

En suma, a tales posiciones no dejan de adherirse no pocos seguidores convictos, que pensando de igual manera pero con talante distinto permanecen ocultos en un silencio oportunista, cuando no algunos de ellos disimulados bajo la aparente asepsia científica del Neopositivismo que profesan: como si de una y otra forma no estuvieran alineados con ninguna teoría. A decir verdad, el ejercicio inocente de una teoría, como la citada, no les exime de una praxis ingenua de la misma.

No cabe duda de que los tiempos han cambiado, y que con ellos el Historicismo Cultural ha entrado en crisis. Los defensores de su orden aparente opinan que estamos inmersos en un "Caos", sin tener una sensibilidad suficiente para darse cuenta, como hemos dicho antes, de que ahora las puertas del diálogo teórico se encuentran abiertas de par en par.

\section{IX.- EL CUESTIONAMIENTO DE LA SOCIEDAD DE CLASES Y DEL ESTADO EN EL MUNDO FENICIO OCCIDENTAL}

Casi a las puertas del año 2000, pisando ya el umbral del siglo XXI, las expectativas investigativas de la Arqueología española, y con ellas las perspectivas de estudio de la sociedad fenicia occidental y de la sociedad tartesia, comienzan a verse liberadas de algunos paradigmas creados por los historiadores y arqueólogos contemporáneos mediante el cultivo del Historicismo Cultural.

El cuestionamiento crítico de estos paradigmas, cuyas raíces decimonónicas hemos visto crecer en diversas troncalidades culturalistas, en relación con las ideologías presentistas de los nacionalismos europeos y españoles del siglo XX, resulta para nosotros sumamente trascendental. Ya que, en definitiva, su revisión pasa en la Península Ibérica por descarnar la matriz de los fundamentos historicistas en los cuales se han venido basando los ideales del "progreso", del así concebido "desarrollo" civilizatorio hasta nuestros días.

Las versiones historicistas que hemos resumido a fin de cuentas obedecen en líneas generales a la justificación de varios modelos invasores, conquistadores y colonizadores, que entre otros han venido sirviendo para construir la imagen de la civilización occidental, en razón de tres modelos concatenantes: el del imperialismo grecorromano durante la Antigüedad, el del imperialismo europeo en la Época Moderna, y el del actual imperialismo capitalista en el llamado Tercer Mundo.

En este sentido, por una parte, el historicismo contemporáneo ha ensalzado el progreso llevado por los griegos y romanos hasta los confines terrestres del mar tenebroso, y por otra parte, después de la Reconquista, una vez que este último quedó convertido en el mar de Colón, lo ha conectado con los modernos destinos, que expandirían los conquistadores y colonizadores al Nuevo Mundo. Pero todavía más, al exponer las matizaciones conceptuales adoptadas por el Historicismo Cultural para conciliarse con los presentismos justificativos de la formación de un espíritu nacional español, en la 
Europa del presente siglo, hemos podido observar también cómo la Arqueología ha contribuido al apoyo de aquellos idealismos, recuperando de las fuentes clásicas versiones historizantes que tampoco dejaron de ser parcialistas y sesgadas. En suma, porque consignaron para la memoria literaria de su HISTORIA ESCRITA una muy pálida visión acerca del acontecer más occidental del referido Mundo Antiguo. O sea, opacando la visión atlántico-mediterránea de un Proceso Histórico dentro del cual la ciudad de Gadir había alcanzado su máxima dimensión como expresión del Estado.

Hemos explicitado, al menos en buena parte, los motivos causantes de que los asentamientos coloniales más antiguos, así como los respectivos territorios fenicios atestiguados por la Arqueología de Campo en las antiguas líneas costeras de Malaka, Sexi, Abdera y Baria, en tanto que fueron ignorados en las citadas fuentes clásicas, no pudieron ser rescatados del olvido hasta después de la pasada década de los años sesenta (Pellicer 1963; Schubart y otros 1969) recibiendo así una renovada consideración histórica. Por cierto, no para menguar, sino para aumentar con creces la valoración capital de Gadir, en la hegemonía política de los mares y litorales situados alrededor del Círculo del Estrecho (Arteaga 1993-1994).

En oposición a las concepciones ideológicamente dominantes, que solían difundir la imagen historizante tras la cual al poder le interesaba ser visto, el discurso histórico referido a los fenicios occidentales para nosotros comportaba, a pesar del silencio interesado de los escritores grecolatinos, un proceso atlántico-mediterráneo que siendo en su dialéctica paralelo al de Grecia, en general, y al de Roma, en particular, difícilmente se puede entender desconectado del desarrollo estatal de Gadir. Por lo que, a nuestro entender, los fenicios occidentales que se identificaban con los gaditanos en el Mundo Antiguo deben ser contrastados al nivel de unos sistemas estatales con los griegos, romanos y cartagineses, para poder vertebrar el papel histórico que realmente jugaron en el Extremo Occidente, y desde allí también en el Mediterráneo.

La expansión marítima que explica la fundación de Gadir por parte de Tiro, como la colonización creciente experimentada por el Mundo Gaditano, más que por las causas particularistas que se vienen aduciendo, para nosotros eran expresiones consecuentes con las proyecciones expansionistas del Estado; la primera metropolitana, estructurada respecto de Oriente, y la segunda colonial, respecto de Occidente; la gaditana.

En esta matización estatal consiste la diferencia abismal que observamos, hasta ahora, entre la propuesta explicativa de la colonización fenicia que nosotros alegamos en relación con la sociedad tartesia, y la que actualmente rehuyen otros colegas al tratar la misma problemática.

No pocas veces, al plantear las cuestiones económicas-sociales de la colonización fenicia, hablan de las vinculaciones relativas a las instituciones identificadas en el palacio y en el templo de Melqart, pero luego al analizar las causas de la colonización éstas se acusan en una atomización de factores: donde el Estado jamás aparece definido, en su decisivo protagonismo político, e ideológico. Es decir, que las superestructuras ideológicas, políticas y religiosas, que se aceptan consolidadas en Gadir, en relación con el templo de Melqart, después no se estudian como justificativas de una sociedad de clases, y por consiguiente mostrativas de un modelo de Estado.

En definitiva, a veces queda mencionada la noción del Estado, como pueden quedar referidas las cuestiones económico-sociales relativas a las relaciones productivas, concernientes a fenicios y tartesios, sin que los mismos autores procedan a tratarlas en profundidad, definiendo cual era el modo de producción en que las mismas se insertaban. Es decir, que al hablar de las relaciones desiguales que plantean entre colonizadores e indígenas, eluden la definición concreta del modo productivo dentro del cual las relaciones sociales de producción, en términos de explotación, desarrollaban sus contradicciones desiguales. Con lo cual, nadando siempre en la superficie, eluden también la explicación de los modos de vida y de los modos de trabajo, que los fenicios y tartesios confrontaban dialécticamente, 
como formaciones económico-sociales clasistas: acaso temiendo por este camino alternativo tener que encontrarse frente a frente con la existencia del Estado, que paradójicamente vienen negando (Plácido y otros 1991), cuando no dejando completamente de lado (AA. VV. 1989; Alvar y Blázquez 1993).

En un estudio reciente, sin ignorar las expectativas estatales de dicho discurso en Oriente, nosotros mismos hemos retomado la lectura del proceso histórico fenicio occidental, para mostrar que desde el Círculo del Estrecho el protagonismo creciente de Gadir era debido a su estructuración como Estado.

Partiendo de los llamados tiempos coloniales, en los cuales la soberanía institucional de Gadir era depositaria de la metropolitana de Tiro, hemos señalado la manera en que los poderes oligárquicos, frente a los aristocráticos tartesios, fueron emergiendo en el Extremo Occidente. Poniendo en evidencia cómo en función del crecimiento de sus círculos productivos, en relación con Gadir, fueron los propios fenicios del Círculo del Estrecho los que protagonizaron una sorprendente expansión estatal, atlántica y mediterránea, hacia los tiempos de la fundación de Ibiza. Para finalmente, al romperse el sistema tributario ejercido desde Tiro, con el surgimiento de las "poleis" en Malaka, Sexi, Abdera y Baria, pasar las mismas a formar alianzas políticas renovadas en el marco de la "Liga de Gadir" (Arteaga 1993-1994). Ocho puntos hemos considerado básicos en el citado estudio, a la hora de introducirnos en la explicitación de este proceso fenicio occidental (Arteaga 1993-1994).

I. La matización histórica entre el concepto colonial del Círculo del Estrecho, y la formación de las ciudadanías integradas en la "Liga de Gadir".

II. La implantación colonial fenicia en el Círculo del Estrecho, como proyección de la soberanía metropolitana de Tiro.

III. Los territorios coloniales y círculos productivos, como modelos explicativos del Mundo Fenicio Occidental.

IV. La expansión del comercio fenicio occidental y la formación de un nuevo círculo productivo colonial en la isla de Ibiza.

V. La emergencia de la "polis" en el Círculo del Estrecho y la formación de la "Liga de Gadir".

VI. La periodización del proceso histórico fenicio-púnico en el Mundo Gaditano, y la instauración del modo antiguo de producción.

VII. La política de las alianzas estatales y de los tratados comerciales.

VIII. El cambio socioeconómico y el comercio institucional.

En los dos primeros apartados, sobre los cuales acabamos de insistir, enfatizábamos el cuestionamiento institucional de la fundación de Gadir, y el referido a su sistema colonial, desde una perspectiva de Estado.

En estrecha relación con el templo de Melqart, en Gadir, la vinculación institucional con Tiro serviría a su vez para establecer respecto del sistema productivo colonial una dependencia tributaria. Siendo la misma administrada para el palacio (como casa real) y para el templo (como casa de dios); ya que en la metrópolis aquellas eran las instituciones máximas del poder soberano. El poder que en lo político y en lo religioso ostentaba el rey de Tiro, como una encarnación viva de Melqart (Aubet 1987 y 1994; Arteaga 1992a y 1993-1994).

No se puede entender el desarrollo de las actividades comerciales y coloniales fenicias, por consiguiente, sin atender a los intereses vinculativos que las clases dominantes pergeñaron a través de las instituciones estatales, aglutinadas en la monarquía divina; para así detentar su poder contando con el respaldo del apoyo soberano. Sobre todo a partir del reinado de Hiram I de Tiro (969-936 a. C.) en adelante. 
Siendo el desarrollo del comercio tirio un factor económico-social dependiente de las relaciones productivas arbitradas por las elites dominantes, a través de las instituciones del Estado, nosotros entendemos que la consolidación de la expansión comercial en relación con la búsqueda de materias primas en el Mundo Tartesio tuvo que afirmarse mediante la explotación directa de nuevas tierras productivas, como aquellas que bajo la tutela de Gadir se fueron ocupando en las costas mediterráneas de Andalucía, y progresivamente también en otros ámbitos litorales cada vez más apartados, en el Atlántico y en el Mediterráneo (Arteaga 1987; 1992a y 1993-1994: 37-51). Habiendo sido fundados desde Gadir, los nuevos asentamientos coloniales quedarían sometidos a través del templo de Melqart al sistema tributario dependiente del poder metropolitano de Tiro. Por lo que pensamos que ya desde los tiempos de Hiram I el Estado tirio estaba organizando el llamado comercio precolonial con los tartesios, a través de la zona marítima del archipiélago atlántico: en el cual pudieron consolidar los fenicios su soberanía, mediante la institución del templo de Melqart, y por lo mismo con mucha antelación a las restantes fundaciones que después se fueron estableciendo en Occidente. El comercio precolonial, dirigido al mar atlántico, sería así prevalentemente "gaditano".

No concuerda esta prelación gaditana, ni la organización de las colonias dependientes del sistema de ocupación de unas nuevas tierras productivas, con la idea actualmente generalizada, pensando estrictamente en Oriente, de que los asentamientos costeros localizados en el litoral mediterráneo de Andalucía se fundaron como derroteros para conducir las navegaciones lejanas hasta Gadir. En cualquier caso, parece que la motivación dominante actuaba a la inversa, facilitando el control de Gadir sobre las colonias, y la dependencia administrativa de las mismas respecto de Gadir: lo cual no obstaría para que las naves orientales y otras embarcaciones que faenaban entre las actuales costas andaluzas y norteafricanas recalaran en las instalaciones portuarias existentes entre Tarifa y Villaricos. Aparte de que los barcos gaditanos, desde los primeros tiempos coloniales, pudieran haber realizado muchas veces la travesía marítima entre el Círculo del Estrecho y los mares orientales.

No faltan, a nuestro entender, evidencias arqueológicas mostrativas de que las navegaciones comerciales fenicias eran así de complejas, entre Oriente y Occidente, pero igualmente a la inversa.

En la misma Cartago, nosotros hemos localizado ánforas y vasijas de barniz rojo, que con seguridad proceden del comercio fenicio occidental. Como a la inversa, hemos señalado la existencia de ánforas cartaginesas en los asentamientos costeros de Andalucía. Y aún más, cerámicas tartesias del Bronce Final, en los almacenes y vertederos de distintas excavaciones de Cartago, que hasta el presente han pasado completamente desapercibidas. Las formas cerámicas y sus decoraciones incisas y bruñidas son exactamente iguales a las que pueden encontrarse desde Huelva, pasando por el Golfo de Cádiz y el Valle del Guadalquivir, a lo largo de las costas mediterráneas de Andalucía.

Sin tener que entrar ahora de lleno en estas cuestiones comerciales, vistas desde Occidente, para nosotros resulta evidente que las mismas no se pueden explicar pensando solamente en naves orientales.

Siendo necesario, respecto de la navegación, remarcar que no eran las corrientes marinas, ni los vientos, ni las dificultades náuticas propias del Estrecho de Gibraltar, las que determinaban las direcciones de los derroteros fenicios, que los arqueólogos simplificamos en nuestros mapas. Aduciendo por nuestra parte que las pautas de navegación establecidas para el tráfico del comercio, así como también las promovidas para la explotación y organización administrativa de los círculos productivos en Occidente (Arteaga 1987 y 1993-1994) aprovechaban el conocimiento de aquellos condicionantes marítimos para utilizarlos y salvarlos de muy disímiles maneras, de acuerdo con las diversas actividades que los navegantes fenicios, entre los más experimentados, eran capaces de conectar con sus barcos.

Eran por consecuencia las decisiones económicas, sociales y políticas de las cuales dependían las navegaciones, las que determinaban sus derroteros; que a pesar de la importancia operativa que tuvieron 
no quedaron "dibujados" para siempre en las estelas que las embarcaciones dejaban sobre el agua. Otro panorama tendríamos, a tenor de las estelas que dejaban las naves gaditanas: a las que se tendría que dedicar una mayor atención, si realmente se quiere admitir que la proyección estatal de Gadir era atlántica y mediterránea, y en este sentido primordialmente marítima.

El segundo aspecto que hemos abordado, en el citado estudio crítico (Arteaga 1993-1994: 32-37) para mostrar las expectativas económico-sociales y sociopolíticas propias de aquella proyección estatal gaditana, ha sido el referido a los círculos productivos fenicios occidentales: retomando la valoración dependiente y complementaria que desde Gadir habíamos planteado diez años antes (Arteaga 19851987), con el objeto de señalar que aparte de los modelos coloniales griegos, que corrientemente los arqueólogos clásicos venían tomando como paradigmas comparativos, los territorios coloniales fenicios estaban estructurados de una manera diferente. Es decir, comportando sus patrones de asentamiento, en relación con Tiro, Cartago y Gadir no la ordenación de un asentamiento aislado, sino la complementación de una dominación territorial abarcada mediante la implantación creciente de varios establecimientos, dependiendo de las actividades productivas desarrolladas en cada círculo colonial (Arteaga 1993-1994: 32-37).

En principio, éste sería durante los siglos VIII y VII a. C., en las costas mediterráneas de Andalucía, el modelo de crecimiento colonial referido al sistema estatal capitalizado por Gadir. Por lo que la integración de nuevos elementos foráneos, en cada momento del proceso histórico fenicio occidental, quedaría también regulada en función de sus propias relaciones sociales de producción, y así adscrita a la ordenación política-administrativa del Círculo del Estrecho.

Tratándose de un crecimiento productivo, que beneficiaba sobre todo a las oligarquías emergentes, en pugna por el poder, se entiende que durante el siglo VII a. C. los intereses económico-sociales gaditanos, sin desligarse del sistema tributario metropolitano, hubieran continuado desarrollando una proyección marítima, hacia las costas atlánticas de África y de Europa, así como también por las mediterráneas hasta el Bajo Ebro, el Ampurdán y el Golfo de León (Arteaga y otros 1978) utilizando como puente de navegación la fundación gaditana de un nuevo círculo colonial situado en la isla de Ibiza (Arteaga 1993-1994: 37-40).

En efecto, la sociopolítica de Gadir, en la potenciación de las clases oligárquicas de las colonias occidentales, supuso la emergencia de unas nuevas instancias de poder, a partir de la segunda mitad del siglo VII a. C., en suma parangonables con las de Tiro y de Cartago. Dándose por ello desde el Círculo del Estrecho aquella gran expansión marítima, partiendo de los círculos productivos fenicios occidentales, hacia cuatro derroteros litorales:

a) Los que pasando por Lixus quedaron reafirmados a través de Mogador, conectando con las rutas del oro y del marfil; adelantándose al "famoso" viaje de Hannon.

b) Los que pasando por Castro Marín (Bajo Guadiana), Rocha Branca (Algarve), Setúbal y Abul (río Sado-Alcacer do Sal), Lisboa (río Tajo), Santa Olaia y Conimbriga (río Modengo) conectaban con las rutas del estaño; adelantándose al viaje de Himilcon.

c) Los que siguiendo la costa norteafricana, hasta Rachgoun en Orán, jalonaban la ruta del atún; comprendiendo también pesquerías organizadas desde los círculos productivos localizados en las costas mediterráneas de Andalucía.

d) Los antes referidos en relación con Ibiza, a la vista de los recientes descubrimientos arqueológicos de Sa Caleta (Ramón 1991) y de Can Partit (Costa 1988). Ya que muy al contrario de cuanto se pensaba 
respecto de los cartagineses como fundadores de un asentamiento en dicha isla, hacia mediados del siglo VII a. C. (Diodoro Sículo 5: 16) ahora sabemos que fueron los fenicios occidentales quienes se establecieron en la misma. Para, a través del litoral valenciano (Guardamar del Segura, Cullera, Bajo Júcar) y el mar de las Baleares, facilitar las navegaciones comerciales que desde los círculos productivos meridionales conectaban con las costas castellonenses (Vinarragell, Bajo Mijares) y del Bajo Ebro (Aldovesa), llegando, así también hasta los confines marítimos del río Herault (Francia) antes de que los griegos foceos se hubieran instalado en Marsella y en Ampurias. Con lo cual, los derroteros mediterráneos que llevaban a Tartessos, antes de hacerse foceos habían sido "gaditanos".

Llegados a este punto, sin ignorar el panorama político del Mediterráneo Oriental, ni los poderes emergentes acusados en las pretensiones imperialistas de los cartagineses en torno a los mares de Sicilia y de Cerdeña, podemos enfatizar que era por entonces cuando la Talasocracia fenicia (referida luego a comienzos del siglo VI a. C. por EZEQUIEL, 27, 12-13) había alcanzado realmente sus máximas cotas hegemónicas: afianzada todavía en las estructuras estatales que se mantenían entre Tiro, Cartago y Gadir.

Esta incuestionable realidad histórica, que a la postre supuso la lucha de unos poderes estatales con otros, y una pugna ideológica por la dominación política del Mediterráneo Occidental, es la que referida de una manera superficial después no se explicita en profundidad, en los textos antiguos que mejor se han conservado y transmitido hasta nuestros días.

Por todo lo antes dicho, ha sido el proceso histórico relativo a los tiempos coloniales fenicios occidentales el que a partir de los tiempos púnicos fueron ocultando cada vez más las referencias dominantes grecorromanas. Comenzando incluso con la versión griega que respecto del Extremo Occidente nos transmite el que desde Roma se consideraba el "Padre de la Historia" (Cic., leg. I, 5). O sea, Herodoto de Halikarnassos, en cuyos relatos no dejaron de incidir ya las mitificaciones historicistas: como aquellas mal disimuladas en relación con el fabuloso viaje realizado por el samio Kolaíos hacia las Columnas de Hércules (Heródotos IV, 152) y como las expresadas para ensalzar la heroicidad de los foceos, arrogándoles el haber descubierto el Adriático, el Tirreno, Iberia y Tartessos (Heródotos I, 163).

Con todos los defectos que se le pueden achacar a la Arqueología, no cabe duda de que ha sido el debate teórico y metodológico librado en su seno, durante los últimos veinte años, el que ha puesto en solfa una nueva plataforma de opinión. Sobre la cual, ahora, se pueden poner en entredicho muchos de los argumentos "documentalistas" que desde sus manipulaciones presentistas no ha dejado de utilizar el Historicismo Cultural. Por su parte, como si el problema relativo al Estado hubiera sido estático, en relación con sus referentes contemporáneos, desde un modelo de progreso civilizatorio iniciado en Grecia, y consolidado a partir de Roma; olvidando por el camino otros antecedentes y consecuentes "enigmas históricos", que así se han opacado en el proceso concerniente a la Antigüedad. Es por ello por lo que otras versiones económico-sociales y sociopolíticas referidas realmente al desarrollo histórico del Estado en el Mediterráneo Occidental, aparte del Modelo Clásico, no le interesan mucho al Historicismo Cultural, que durante décadas ha operado con sus particulares comparaciones civilizatorias, revistiendo con ellas las "bondades" del modelo de progreso contemporáneo. Ya que este último, justificándose en las "imágenes" prestadas de una muy concreta "Antigüedad", las ha promovido como unas esencias del presente, siendo a fin de cuentas el que con su ayuda se ha venido reproduciendo para la ideología dominante, a partir del Mundo Moderno. Por ello, vale la pena retomar la Antigüedad, no desde la expectativa culturalista de la civilización occidental, sino desde el proceso histórico del desarrollo del Estado. 
Antes de que Roma hiciera suya a fuerza de poder la dimensión marítima de la ecúmene griega, cuya noción llegaba hasta el ámbito transfretano de las Columnas de Hércules, lo cierto es que a tenor de las evidencias arqueológicas actuales podemos afirmar que se dieron en la Península Ibérica unas profundas transformaciones económico-sociales, sociopolíticas y socioculturales, que no por ignoradas estaban desconectadas del discurso histórico del Mundo Antiguo Mediterráneo. Nos estamos refiriendo sobre todo a la formación del Mundo Ibérico (Arribas 1965), y a las sociedades que encarnaban su emergencia.

En estrecha relación con el proceso formativo de tales sociedades ibéricas (Ruiz y Molinos 1992), las nuevas ordenaciones territoriales que se consolidaron a todo lo largo del litoral mediterráneo, así como en su hinterland, coincidieron a la inversa con la retracción sociopolítica observada tanto en la dialéctica del Mundo Tartesio, como en la propia del Mundo Fenicio Occidental. Sin que se tratara, en extremo, de una causalidad efectista, aquella retracción en cuanto a los fenicios occidentales tuvo que verse acelerada a partir de la Caída de Tiro; que por su parte motivaría un cierto desequilibrio en el sistema organizativo colonial; pero no en las relaciones productivas que en los territorios del Círculo del Estrecho se continuaron desarrollando.

Aprovecharon estas circunstancias en cualquier caso los griegos foceos, que ya venían comerciando con los fenicios occidentales en la llamada "palaiápolis" de Ampurias, para en el transcurso del nuevo panorama político afincarse en la tierra firme (Neápolis), y durante un buen período de tiempo imponer su Talasocracia en las rutas comerciales del Mediodía. Dándole también la arqueología una veracidad absoluta a los derroteros que los griegos siguieron, para frecuentar los puertos atlántico-mediterráneos, durante el apogeo de la monarquía tartesia del rey Argantonios. Este era por lo tanto el período histórico que recordado por Heródotos (I, 163) comenzaría a referirse a lejanías de tiempos, espacios y pueblos, desde la perspectiva de la ecúmene griega, y no desde los espacios sociales que hacia Occidente quedaban así abstraídos de su devenir histórico. Las antiguas referencias escritas, sin embargo, muestran distintas cadencias, que vale la pena retener. Las fuentes griegas, sobre los tiempos coloniales referidos a las costas mediterráneas de Andalucía, son como se ha dicho prácticamente nulas. Cuando los focenses entraron en acción, se mostraban obsesionadas y atraídas por Tartessos. Y cuando Roma comenzó a mostrar su intervención política, a partir del tratado del 509, las referencias se hicieron además de oscuras sumamente contradictorias. De manera que van a ser los textos grecolatinos desde el Helenismo hasta la conquista romana los que procedan a integrar al Extremo Occidente en el orbe del Mare Nostrum. Cuando Estrabón escribe su Geografía, tanto Gadir como los Turdetanos se contemplaban como formando parte de Roma. Esto último demuestra que el proceso histórico anterior, bajo el peso del Imperio, había quedado subsumido en otro pasado, considerándose en los tiempos de Augusto como una integración romana. Nos interesa remarcar estos matices, respecto de la historiografía grecolatina, porque permiten fijar la atención en la época más oscura y a la vez más decisiva del proceso histórico aludido: la época de transición, entre el llamado mundo colonial y el mundo púnico. La misma que supuso la retracción del mundo tartesio, para por otra parte conocer la emergencia del mundo ibérico.

En suma, la realidad fenicia occidental se hizo ignota, y la tartesia se hizo mítica, en consonancia con la ideología griega que así las requería. Los puertos ibéricos, y los puertos fenicios, frecuentados por los navegantes jonios, comenzaron a mencionarse con nombres tales como los de Hemeroskopeion y Mainake (Arteaga 1976-1978: 48-49).

Hacia las periferias del Mundo Tartesio, las jóvenes aristocracias ibéricas se hicieron más proclives a un pacto comercial independiente con los griegos, siendo entre las mismas donde las connotaciones ideológicas de los héroes y guerreros más quedaron sublimadas, en correspondencia con el modo 
productivo que por su parte ellas implantaron. Diferentes organizaciones estatales se consolidaron en la explotación de territorios vecinos, con fronteras. En fin, demarcando la instauración de sus diversos sistemas productivos, que en la potenciación de las estructuras económico-sociales definidas como ibéricas se tradujeron en identidades sociopolíticas y socioculturales.

Es por todo lo antes dicho por lo que el proceso histórico relativo al panorama económico-social y sociopolítico de la Península Ibérica, durante el siglo VI a. C., debe ser analizado desde Occidente, a tenor de su visión de conjunto. Aunque solo sea para plantear unas alternativas explicativas más complejas y globales, saliendo así al paso de otras argumentaciones especulativas que por cauces particularistas y deterministas han venido simplificando la interpretación de la llamada "crisis" en Tartessos, como si hubiera constituido un fenómeno particularizado.

Olvidan por completo que las citadas transformaciones sociales, definidas en los amplios territorios antes aludidos por sus respectivas estructuras económicas, y por sus correspondientes superestructuras ideológicas y políticas, fueron las que se plasmaron en distintas formas de estatalización, referidas en el tiempo y en el espacio también al mundo turdetano.

Teniendo en cuenta estas consideraciones, nosotros parangonamos frente a los sistemas aristocráticos Ibéricos (Ruiz y Molinos 1992), las concernientes a los sistemas oligárquicos fenicios occidentales (Arteaga 1992a) que siendo emergentes del anterior sistema colonial pasaron con la administración de sus propios recursos a la afirmación de unas instituciones ciudadanas. Es decir, aquellas que estructuradas como "poleis" (Arteaga 1990) a partir del siglo VI a. C. conoceremos integradas en la denominada por nosotros "Liga Púnica Gaditana" (Arteaga 1992a y 1993-1994).

Como hemos expuesto en los trabajos arriba citados, pensamos que fueron aquellas relaciones sociales de producción, capitalizadas por las oligarquías dominantes en unas poleis como Malaka, Sexi, Abdera y Baria, entre otras, las que transformaron la fisonomía de los nuevos espacios sociales; que las fuentes escritas ignoraron, y la arqueología de campo nos refiere a los tiempos púnicos. Bien sea en atención a los espacios urbanos, bien sea en atención a los medios rurales y paisajes funerarios (Arteaga 1990). Siendo todo ello probatorio de que la transformación económico-social operada entre los fenicios occidentales, una vez avanzado su proceso de desarrollo, independiente respecto de Tiro, a la larga pudo verificarse en un salto cualitativo, respecto del modo de producción antes operante, viéndose él mismo correspondido por unas superestructuras ideológicas y religiosas, que siendo justificativas del cambio fueron las que en los espacios sociales plasmaron el orden y la imagen que los nuevos poderes se interesaban en mostrar: ahora en connivencia con Cartago.

No en balde, la contrastación económico-social del modo productivo emergente con las "poleis" púnicas, con sus correspondientes manifestaciones ideológicas y religiosas, permite plantear respecto de los cartagineses y otros pueblos semitas, a partir del siglo VI a. C., una dicotomía etnográfica de orden parecido al que por otra parte, en las periferias de los territorios fenicios y tartesios, a distintos niveles de identificación, asumieron respecto de los griegos las aristocracias ibéricas para reafirmar su poder.

Muchos de los supuestos culturales, y en particular los artísticos, que se manifestaron como identitarios de los pueblos integrados en aquel proceso histórico peninsular, por consiguiente, no fueron ideológicamente ingenuos. Ya que la definición política de aquellas organizaciones estatales requerían detentar el dominio de un marco conceptual, del que no podía escapar la utilización ideológica de la cultura, y de la religión. Lo mismo puede traducirse desde la lectura social del Arte; que en apoyo de tales manifestaciones quedaría al servicio del poder, para reforzar en la conciencia social la imagen que les interesaba transmitir a las clases dominantes. 
En la sociedad aristocrática de los jóvenes estados ibéricos, por tanto, con el culto heroizante de los Príncipes se reforzaba la ideología del poder. Los templos y santuarios ibéricos, en grandes espacios territoriales, eran igualmente depositarios de tales recursos de concienciación.

Las proyecciones ideológicas de las pugnas estatales, donde quizás mejor las vemos expresadas es en los predicamentos económico-político-religiosos que desde el siglo VI a. C. en adelante refrendaron en relación con Occidente los famosos tratados comerciales y mercantiles. Lo cual quiere decir, sin entrar ahora en la matización de las formas de intercambio propias del llamado comercio aristocrático, respecto de las formas del llamado comercio institucional, que este último no dejaba de traducir el punto crítico al que habían llegado los intereses económico-sociales de las distintas "poleis", confrontadas en el Mediterráneo Oriental, Central y Occidental (Arteaga 1992a).

Las alianzas que al respecto se suscitaron, vistas como ligas económico-político-religiosas, tanto en los dominios territoriales, como en los ámbitos marítimos, se hicieron consustanciales con los propósitos expansivos de dichas poleis. Por lo que los modelos confederativos que, traducen dichos tratados, siendo políticos, pueden verse comparados en relación con Esparta, Corinto, Atenas, Roma, Cartago; y a pesar de las pocas noticias que transmiten las fuentes escritas acerca de los fenicios occidentales, también en relación con Gadir.

En consecuencia, dada su vinculación estrecha con la propia emergencia de la sociedad aristocrática tartesia, ofrece el proceso histórico fenicio occidental un marco dialéctico que a tenor de cuatro grandes puntos referenciales pasa de una manera prioritaria por el reconocimiento de Gadir como Estado. Primero, en cuanto a su función como ciudad depositaria de las instituciones coloniales del Estado tirio y organizadora de su sistema administrativo tributario en Occidente; segundo, en tanto que capitalidad garante del régimen de explotación clasista sobre el cual se desarrollaba el crecimiento productivo en las tierras colonizadas y mares controlados alrededor del Círculo del Estrecho de Gibraltar; tercero, por su hegemonía política y expansiva, fundando durante el siglo VII a. C. nuevos asentamientos atlánticos y mediterráneos, dependiendo de los circuitos productivos meridionales, y cuarto, en razón de haber seguido aglutinando los intereses económico-sociales y sociopolíticos de las clases oligárquicas dominantes en las "poleis", que durante los tiempos prerromanos aparte de mantener su alianza con Cartago quedaron a través del "Heracleion" vinculadas a la "Liga de Gadir" (Arteaga 1992a y 1993-1994).

Para poder recuperar el marco dialéctico que concierne al proceso histórico fenicio occidental, con Gadir a la cabeza frente a otros Estados mediterráneos, la revisión historiográfica del renovado concepto de "Civilización" debe comenzar en el seno de los nacionalismos europeos que lo han acuñado a su arbitrio, tomando de la "Antigüedad" las "imágenes" representativas que más han interesado para justificar y encubrir sus propios "proyectos civilizatorios". Lo cual, visto desde una óptica diferente, no puede ocultar que el criterio aparentemente inocente de la expansión de la civilización conlleva una forma encubierta de la expansión del Estado.

Detrás de la noción burguesa del "desarrollo", amparada en el concepto del "progreso" para llegar a la "civilización", lo que se ha enmascarado realmente por parte de las ideologías del poder, con la ayuda del Historicismo Cultural, ha sido el proceso histórico económico, social y político que también en el Extremo Occidente atlántico-mediterráneo le concierne al desarrollo del Estado. Desde sus formas prístinas, solamente contrastables con otros procesos relativoś a las sociedades clasistas iniciales (Arteaga y Roos 1992 y 1995) que emergiendo de la jerarquización de la sociedad tribal (Arteaga 1992b) se conocen en Mesopotamia, en Egipto, en la India, en el río Amarillo de China, en Mesoamérica y en Sudamérica, hasta llegar a la confrontación de los Estados actuales: pasando en la Península Ibérica por aquellas "formas intermedias" relativas al Mundo Antiguo, que en relación con las sociedades fenicias 
occidentales, tartesias e ibéricas hemos concatenado dialécticamente en el presente trabajo, como propias del desarrollo histórico prerromano, romano, medieval y moderno del Estado en Europa.

Convencidos también por nuestra parte de que la vieja historiografía, ella misma, forma parte de su historia, y de que al descubrirla como ideología damos un paso hacia la ciencia (Vilar 1973), esperamos que nuestra crítica contribuya no sólamente a mostrar por qué el Historicismo Cultural ha venido siendo un arma de la reacción (Fontana 1973; Rodríguez 1974; Prieto 1976), sino también para evidenciar desde la Arqueología las razones por las cuales muchos "enigmas del pasado" han quedado soterrados bajo otros que selectivamente se han hecho remanecer para una vez rememorados construir con ellos en singular y en plural la idea de una supuesta "unidad de destino en lo universal" (Barbero y Vigil 1978: 20). En última instancia, para resolver de esta forma lo que se ha tomado como un acuciante problema de conciencia: "la imperfección de España para seguir el rumbo de la civilización occidental hacia el capitalismo, el liberalismo y el racionalismo, en el triple aspecto económico, político y cultural" (Vicens Vives 1968: 21; Barbero y Vigil 1978: 19).

\section{BIBLIOGRAFÍA.}

AA. VV. (1969): Tartessos y sus problemas (V S. I. P. P.). Barcelona. (1976-78): Simposi Internacional "Els Origens del Món Ibèric", en Ampurias 38-40.

(1986): Homenaje a Luis Siret (1934/1984). Sevilla, Consejería de Cultura de la Junta de Andalucía. (1987): I Jornadas sobre el Mundo Ibérico / Jaén, 1985. Jaén, Consejería de Cultura de la Junta de Andalucía/Ayuntamiento de Jaén.

(1989): Tartessos. Arqueología Protohistórica del Bajo Guadalquivir. Coord. de M. E. Aubet. Sabadell. Ed. Ausa.

ACQUARO, E. (1978): Cartagine: un impero sul Mediterráneo. Roma.

ALCARARAZ, F. M. (1991): "Excavaciones arqueológicas de urgencias en Villaricos. Cuevas del Almanzora, Almería", Anuario Arqueológico de Andalucía (1989), vol. III: 30-32. Sevilla.

ALMAGRO, M. (1952): "La España de las Invasiones Célticas", en Historia de España, Menéndez Pidal, ed., T. I, vol. II. Madrid.

- (1953): Las necrópolis de Ampurias. Barcelona.

- (1975): Introducción al estudio de la prehistoria y de la arqueología de campo. Guadarrama, $5^{\mathbf{a}}$ ed. Madrid.

ALVAR, J. y BLÁZQUEZ, J. M. (Eds) (1993): Los enigmas de Tarteso.

ARRIBAS, A. (1965): Los íberos. Ayma. Barcelona.

y ARTEAGA, O. (1975): El yacimiento fenicio de la desembocadura del río Guadalhorce (Málaga). Univ. de Granada. Granada.

ARRIBAS, A. y GRUPO O. J. E. DE MÁLAGA. (1969): “El yacimiento paleopúnico de la desembocadura del río Guadalhorce (Málaga)", X CNA (Mahón, 1967): 359-362. Zaragoza.

ARRIBAS, A. y WILKINS, J. (1971): La necrópolis fenicia del Cortijo de las Sombras (Frigiliana, Málaga). Granada.

ARTEAGA, O. (1976-1978): "Problemática general de la iberización en Andalucía Oriental y en el Sudeste de la Península", Ampurias 38-40: 23-60.

(1979): "Avances sobre las nuevas excavaciones en el Cerro del Mar. Campaña de 1976", Not. Arq. Hisp. 6: 261-274. Madrid. 
(1981): Las influencias púnicas. La Baja Época de la Cultura ibérica. Mesa Redonda (1979):

117-141. Madrid.

- (1985a): "Excavaciones arqueológicas en el Cerro del Mar. (Campaña, 1982)", Not. Arq. Hisp.

23: 197-233. Madrid.

- (1985b): "Excavaciones arqueológicas sistemáticas en el Cerro Los Alcores (Porcuna, Jaén). Informe preliminar sobre la campaña de 1985", Anuario Arqueológico de Andalucía (1985): 279-288. Sevilla.

(1985c): "Los hornos romanos del Manganeto, Almayate Bajo (Málaga)", Not. Arq. Hisp. 23: 186.

Madrid.

(1987): "Perspectivas espacio-temporales de la colonización fenicia occidental", Iberos. I Jornadas

Arqueológicas sobre el Mundo Ibérico (1985): 205-228. Jaén.

_ (1988): "Zur phönizischen hafensituation von Toscanos", Madrider Beiträge 14: 127-141. Mainz.

(1990): "La formación del mundo púnico" en Schubart y Arteaga, La colonización fenicia y púnica.

Historia de España, 1, (ed. Planeta): 431-469. Barcelona.

- (1992a): "Las ánforas: púnicas, tardopúnicas, ibéricas y corintias", Junta de Andalucía. Consejería

de Cultura y Medio Ambiente. Andalucía y el Mediterráneo: 104-111. Sevilla.

_ (1992b): "Tribalización, Jerarquización y Estado en el territorio de El Argar", Spal 1: 179-208. (1993-1994): "La Liga Púnica Gaditana", Govern Balear. VII Jornadas de Arqueología Fenicio-púnica (Ibiza, 1993): 23-57. Ibiza.

(1995): Estudio Preliminar: a L. Siret, Villaricos y Herrerías. Reedición de Arráez Editores. Colección Siret de Arqueología, 3: XI-XXX. Almería.

- y HOFFMANN, G. (1990): "Dialéctica del proceso Natural y sociohistórico en las costas mediterráneas de Andalucía”, AEQUA, Monografía sobre Andalucía Oriental. (en prensa).

ARTEAGA, O. y ROOS, A. M. (1992): "El proyecto geoarqueológico de Las Marismas del Guadalquivir. Perspectivas arqueológicas de la campaña de 1992", Anuario Arqueológico de Andalucía / 1992. Actividades Sistemáticas. Sevilla, Junta de Andalucía (en prensa).

- (1995): "Geoarchäologische Forschungen im Umkreis der Marismas am Río Guadalquivir (Niederandalusien)", Madrider Mitteilungen 36: 199-218.

ARTEAGA, O.; HOFFMANN, G.; SCHUBART, H. y SCHULZ, H. (1985): "Investigaciones geológicas y arqueológicas sobre los cambios de la línea costera en el litoral de la Andalucía mediterránea. Informe preliminar", Anuario Arqueológico de Andalucía: 117-122. Sevilla.

- (1988): "Geologisch-archäologische Forschungen zum verlauf der andalusischen Mittelmeerküste", en Forschungen zum verlauf der andalusischen Mittelmeerküste. Madrider Beiträge 14: 107-126. Mainz.

ARTEAGA, O. y MESADO, N. (1979): "Vinarragell”, Madrider Mitteilungen 20: 107-132.

ARTEAGA, O.; NAVAS RODRÍGUEZ, J.; RAMOS MUÑOZ, J. y ROOS, A. M. (1992): Excavación de urgencia en el Peñón de Salobreña (Granada). Ayuntamiento de Salobreña. Salobreña.

ARTEAGA, O.; PADRÓ, J. y SANMARTÍ, E. (1978): "El factor fenici a les costes catalanes i el golf de Lió", 2 Coloqui Internacional d'Arqueología de Puigcerdá (1976): 129-135. Puigcerdá.

ARTEAGA, O. y SERNA, M. R. (1973): "Los Saladares. Un yacimiento protohistórico en la región del Bajo Segura", XII CNA (Jaén, 1971): 437-450. Zaragoza.

_ (1974): "Die Ausgrabungen von Los Saladares (prov. Alicante)", Madrider Mitteilungen 15: 108-121.

- (1975): "Los Saladares-71", Not. Arq. Hisp., 3: 7-140. Madrid.

ASTRUC, M. (1951): "La necrópolis de Villaricos", Inf. Mem. 16. Madrid.

AUBET, M. E. (1974): "Excavaciones en Las Chorreras (Mezquitilla, Málaga)”, Pyrenae 10: 79-108.

- (1987-1994): Tiro y las colonias fenicias de Occidente. Barcelona. 
(1989): Tartessos. Arqueología protohistórica del Bajo Guadalquivir. Ausa. Sabadell.

(1993): "Proyecto: Cerro del Villar, Guadalhorce (Málaga)", Junta de Andalucía. Investigaciones arqueológicas en Andalucía 1985-1992. Proyectos: 471-479. Huelva.

- (1994): "Excavaciones en el Cerro del Villar (Guadalhorce, Málaga)", Anuario Arqueológico de Andalucía (1991), vol III: 346-349. Sevilla.

— y CARULLA, N. (1987): "El asentamiento fenicio del Cerro del Villar (Málaga): arqueología y paleogeografía del Guadalhorce y de su interland", Anuario Arqueológico de Andalucía (1986), vol II: 425-430. Sevilla.

AUBET, M. E.; CZARNETZKI, A.; DOMÍNGUEZ, C.; GAMER-WALLERT, I. y TRELLISO, L. (1991): Sepulturas fenicias en Lagos (Vélez, Málaga). Junta de Andalucía. Sevilla.

AUBET, M. E.; MAAS-LINDEMANN, G. y SCHUBART, H. (1979): "Chorreras. Un asentamiento fenicio al Este de la desembocadura del Algarrobo", Not. Arq. Hisp. 6: 91-138. Madrid.

BARCELÓ, P. A. (1988): Karthago und die Iberische halbinsel von del Barkiden. Bonn.

BARBERO, A. y VIGIL, M. (1978): La formación del feudalismo en la Península Ibérica. Ed. Crítica. Barcelona.

BATE, L. F. (1982): Sociedad, Formación Económico social y Cultura. Ediciones de Cultura Popular. México.

BELTRÁN, J. y GASCÓ, F. (Eds.) (1994): La Antigüedad como argumento. Historiografía de Arqueología e Historia Antigua en Andalucía. Sevilla.

BERNAL, M. (1987): "Black Athena. The Afroasiatic Roots of Classical Civilization. I The Fabrication of Ancient Greece 1785-1985. London.

BISI, A. M. (1983): "L'espansione fenicia in Spagna", Fenici e arabi nel Mediterraneo (1981): 97151. Roma.

BLANCO, A. (1956): "Orientalia. Estudio de objetos fenicios y orientalizantes en la Península", $A . E$. A. 29: 3-31.

(1960): "Orientalia II", A. E. A. 38: 3-43.

BLÁZQUEZ, J. M. (1968): Tartessos y los orígenes de la colonización fenicia en Occidente. Salamanca. (1992): Fenicios, griegos y cartagineses en Occidente. Cátedra. Madrid.

BLECH, M. (1995): "Schulten y Tartessos", La Antigüedad como Argumento II: 177-200. Sevilla.

BONDÍ, S. F. (1978): "Economía fenicia. Impresa privata e ruolo dello Stavo", EVO 1: 139-149.

(1983): "I fenici in Occidente. Modes de contacts et processus de transformation dans les sociétés anciennes", Actes an Colloque de Cortone (1981): 379-407. Pise-Roma.

(1988): "Sull'organizzazione dell'attività commerciale nella società fenicia", Stato, economía, lavoro nel Vicino Oriente Antico: 348-362. Milano.

BONSOR, G. (1899): "Les colonies agricoles pré-romaines de la Vallée du Bétis", Rev. Arch. XXVV: 126-270. Paris.

BOSCH, P. (1928): "Problemas de la colonización fenicia de España y del Mediterráneo Occidental", RO LX: 314-348.

- (1932): Etnología de la Península Ibérica. Barcelona.

(1945): El poblamiento antiguo y la formación de los pueblos de España. México.

— (1952): "Problemas de la historia fenicia en el extremo Occidente", Zephyrus III: 15-30.

- (1953): "La España de todos", Las Españas 23-25.

- (1963): "La Tragedia de España", Las Españas, (discurso).

(1972a): "Cataluña y España", Xaloc 50.

(1972b): "Andalucía", Revista Mexicana de Cultura. 
CABRÉ, J. (1925): “Arquitectura hispánica. El sepulcro de Toya”, Arch. Esp. de Arte y Arqueología I.

(1944): "Corpus Vasorum Hispanorum. La Cerámica de Azaila", C. S. I. C. Madrid.

CALVO, J. y CABRÉ, J. (1919): "Excavaciones en la Cueva y Collado de los Jardines, Santa Elena, Jaén", Memorias de la Junta Superior de Excavaciones Arqueológicas 22. Madrid.

CAMÓN, J. (1954): Las artes y los pueblos de la España primitiva. Madrid.

CARO BAROJA, J. (1946): Los pueblos de España. Barcelona.

CARRILERO MILLÁN, M. (1992): "El proceso de transfọmación de las sociedades indígenas de la periferia tartésica", La colonización fenicia en el Sur de la Península Ibérica. 100 años de Investigación (1990): 117-142. Almería.

CASTRO, A. (1966): La realidad histórica de España. Porrúa. México (=reelaboración de España en su historia: cristianos, moros y judios, publicada en 1948).

CORTADELLA MORRAL, J. (1988): "M. Almagro y la idea de la unidad de España", Homenaje al profesor Marcelo Vigil, vol. II, St Hist VI: 2-35.

COSTA, B. (1988): "Los enterramientos de Can Partit (Necrópolis Puig des Molins) Ibiza (Baleares): Una pérdida irreparable del Patrimonio Arqueológico", Espacios Europeos, año 2, 6: 52-56.

CRUZ, G. (1987): "Un acercamiento historiográfico al Tartessos de Schulten", Baetica 10.

- y WULFF ALONSO, F. (1994): "Tartessos en la Historiografía del XVIII a la del XX: creación, muerte y resurrección de un pasado utópico", en La Antigüedad como Argumento (Beltrán y Gascó Eds.): 171-189. Sevilla.

DE LAIGNE, P. (1897): "Les nécropoles phéniciennes en Andalousie", Rev. Arch. 33. Paris.

DEL OLMO, L. y AUBET, M. E. (Eds.) (1986): "Los fenicios en la Península Ibérica", AuO III-IV (1985-1986).

FERNÁNDEZ BARBERA, J. (1989): "Presencia púnica en la isla de Tarifa", Cuad. Arch. Municipal de Ceuta 5: 7-15.

FERNÁNDEZ MIRANDA, M. y CABALLERO, L. (1975): Abdera. Excavaciones en el Cerro de Montecristo (Adra, Almería) (EAE 85). Madrid, Ministerio de Cultura.

FLETCHER, D. (1949): "En defensa del Iberismo", Anales del Centro de Cultura Valenciana 23.

- PLA, E. y ALCACER, J. (1965-1969): "La Bastida de Les Alcuses (Mogente, Valencia) I y II", T. V. S. I. P. 24 y 25.

FONTANA, J. (1973): La Historia. Barcelona.

FRANKENSTEIN, S. (1979): "The phoenicians in the Far West: a Function of Neo-Assyrian Imperialism", Larsen, M. (Ed.) Power and propaganda. Mesopotamia 7: 263-294.

GAMER, G. (1972): "Las excavaciones en el Cerro del Mar, 1971", Not. Arq. Hisp. 1: 45-50. Madrid.

GÁNDARA, M. (1994): "Consecuencias metodológicas de la adopción de una ontología de la cultura: una perspectiva desde la arqueología", en Metodología y Cultura. Serie Pensar la Cultura. Conaculta. México.

GARCÍA Y BELLIDO, A. (1942): Fenicios y Cartagineses en Occidente. Madrid.

- (1943a): "Algunos problemas de Arte y Cronología Ibéricos", Arch. Esp. Arq. XVI. 1941. Madrid. (1948): Hispania Graeca. Barcelona.

(1960): "Inventario de los jarros púnico-tartésicos", Arch. Esp. Arq. 33: 54.

(1964): "Nuevos jarros tartesios", Arch. Esp. Arq. 33: 50. 
GASCÓ, F. (1994): "Historiadores, falsarios y estudiosos de las antigüedades andaluzas", en $L a$ Antigüedad como Argumento (Beltrán y Gascó Eds.): 9-28. Sevilla.

GEHRIG, U. y NIEMEYER, H. G. (1990): Die phönizier im Zeitalter Homers. Philipp von Zabern. Mainz am Rhein.

GIL-MASCARELL, M. y ARANEGUI GASCÓ, C. (1981): "El Bronce Final y el comienzo de la Edad del Hierro en el país Valenciano", Monografías del Laboratorio de Arqueología 1. Valencia.

GONZÁLEZ WAGNER, C. (1983): “Aproximación al proceso histórico de Tartessos”, Arch. Esp. Arq. 56: 3-36.

- (1990): "La jefatura como instrumento de análisis del historiador", Cuestiones teóricas y metodológicas. Espacio y organización social: 91-108. Madrid.

- (1992): "Tartessos en la Historiografía: una revisión crítica", La colonización fenicia en el Sur de la Península Ibérica. 100 años de investigación (1990): 81-115. Almería.

— y ALVAR, J. (1989): "Fenicios en Occidente: la colonización agrícola", R. S. F. XVII, 1: 61-102. GRAN AYMERICH, J. M. J. (1988): "Málaga fenicio-púnica y el estrecho de Gibraltar", A. C. I. E. G., vol. I: 577-592. Madrid.

— y ALEXANDROPOULOS, J. (1987): "Fouilles a Málaga et recherches phenico-puniques dans la región de Gibraltar", MCV XXIII: 523- 529.

HIRALDO, R. F.; RECIO, A. y RIÑONES, A. (1992): "Castillo de Fuengirola (Málaga). Sondeos "P”“", Anuario Arqueológico de Andalucía (1990), vol III: 313-320. Sevilla.

HIRALDO, R. F. y RIÑONES, A. (1991): "Castillo de Fuengirola (Málaga). Sondeos A, B y H”, Anuario Arqueológico de Andalucía (1989), vol III: 343-350. Sevilla.

HOFFMANN, G. (1988): "Holozänstratigraphie und Küstenlinienverlagerung an der andalusischen Mittelmeerküste", Berichte aus dem Fachberich Geowisswnchaften der Universität Bremen 2. Bremen.

ISSERLIN, B. S. J. (1975): "Informe sobre las excavaciones arqueológicas en Málaga, 1974", Jábega XII: 6-11. Málaga.

KOCH, M. (1984): "Tarschich und Tartessos", Madrider Forschungen 14.

KUHN, Th. S. (1962): The Structure of Scientific Revolutions. University of Chicago Press.

LLOBREGAT, E. (1969): "El poblado de la cultura del Bronce Valenciano de la Serra Grossa, Alicante", Papeles del Laboratorio de Arqueología de Valencia 6: 31-70.

(1972): Contestania Ibérica. Alicante.

LÓPEZ CASTRO, J. L. (1992): "La colonización fenicia en la Península Ibérica: 100 años de investigación", Actas del Seminario (1990): 11-79. Almería.

- (1995): Hispania Poena. Los fenicios en la Hispania Romana. Ed. Crítica. Barcelona.

- y CARRILERO, M. (Coord.) (1992): "La colonización fenicia en el Sur de la Península Ibérica. 100 años de investigación”, Actas del Seminario (1990). Almería.

LÓPEZ CASTRO, J. L.; CARRILERO, M.; SUÁREZ, A.; AGUAYO, P.; SAN MARTÍN, C. y GARCÍA LÓPEZ, J. L. (1991): "La colonización fenicia en Abdera: nuevas aportaciones", II C. I. S. F. P., vol. III: 981-989. Roma.

LÓPEZ CASTRO, J. L.; SAN MARTÍN, C. y ESCORIZA, T. (1988): "Memoria de la excavación de urgencia en Cabecico de Parra de Almizaraque (Cuevas del Almanzora, Almería)", Anuario Arqueológico de Andalucía, vol. III: 7-11. Sevilla.

LUMBRERAS, L. G. (1974): La Arqueología como ciencia social. Ediciones Histar. Lima.

MALUQUER, J. (1965): "Prólogo", de Los Iberos de A. Arribas: 9-20. Ayma. Barcelona.

— (1965): "Los fenicios en Cataluña", Tartessos. V Symp. Int. Preh. Pen.: 251. Barcelona.

MARIANA, J. de (1592-1605): Historia General de España. 
MARTÍN BUENO, M. (1988): "Arqueología subacuática en el Estrecho de Gibraltar”, A. C. I. E. G., vol. I: 71-83. Madrid.

MARTÍNEZ SANTAOLALLA, J. (1946): Esquema paletnológico de la Península Ibérica. Madrid. MELTZER, O. (1878-1896): Geschichte der Karthager. 2 vols. Berlín.

MOLINA FAJARDO, F. (1984): "Nuevos hallazgos fenicios en Almuñécar", A. A. H., II: 53-68. Granada. - (1986): "Almuñécar a la luz de los nuevos hallazgos fenicios", en Los fenicios en la Península Ibérica, vol. I: 193-216. Sabadell.

— ; RUIZ, A. y HUERTAS, C. (1982): Almuñécar en la Antigüedad. La necrópolis fenicio-púnica de Puente de Noy. Granada.

MOSCATI, S. (1972): I fenici e Cartagine. Torino.

MOVERS, F. K. (1841-1850): Die phönizier. 4 vols. Bonn-Berlín.

NIEMEYER, H. G. (1962): "Feldbegehung bei Torre del Mar (prov. Málaga)", Madrider Mitteilungen 3: $38-44$.

(1979): "Toscanos. Campañas de 1973 y 1976", Not. Arq. Hisp. 6: 221-258. Madrid.

(1982a) (ed.): "Phönizier im Westen", Madrider Beiträge 8. Mainz.

(1982b): "Die phönizische Niederlassung Toscanos: eine Zwischenbilanz. Die Phönizier im Westen", Madrider Beiträge 8: 185-204. Mainz.

— ; BRIESE, C. y BAHNEMANN, R. (1988): "Die Untersuchungen auf dem Cerro del Peñón", Madrider Beiträge 14: 155-171. Mainz.

NIEMEYER, H. G. y SCHUBART, H. (1968): “Toscanos und Trayamar”, Madrider Mitteilungen 9: 76-105.

PELLICER, M. (1963): Excavaciones en la necrópolis púnica "Laurita" del Cerro de San Cristóbal (Almuñécar, Granada) (EAE 17). Madrid, Ministerio de Cultura. (1995): Tras la identidad de la Arqueología. Nerja.

— ; MENANTEAU, L. y ROUILLARD, P. (1973): "Para una metodología de localización de colonias fenicias en las costas ibéricas: el Cerro del Pradó", Habis 8: 217-251.

PELLICER, M.; NIEMEYER, H. G. y SCHUBART, H. (1966): "La factoría paleopúnica en la desembocadura del río Algarrobo (Málaga)", IX CNA: 246-249. Zaragoza.

PELLICER, M. y SCHÜLE, W. (1962): El Cerro del Real, Galera (Granada) (EAE 12). Madrid, Ministerio de Cultura.

- (1966): El Cerro del Real (Galera, Granada). El corte Estratigráfico IX (EAE 52). Madrid, Ministerio de Cultura.

PÉREZ BAYER, F. (1772): Del alfabeto y lengua de los fenices y de sus colonias. Madrid.

PERICOT, L. (1950): La España primitiva. Barcelona.

- (1958): "España antigua", en Historia de España, 2a . ed. Barcelona.

PIETSCHMANN, R. (1889): Geschichte der Phönizier. Berlín.

PLA, E. (1959): "El problema del tránsito de la Edad del Bronce a la del Hierro en la región valenciana", $V$ CNA (1957): 128-133. Zaragoza.

_ (1962): "Nota preliminar sobre "Los Villares" Caudete de las Fuentes, Valencia", VII CNA (1960): 233-239. Zaragoza.

PRIETO, A. (1976): La historia como arma de la reacción. Akal. Madrid.

QUINTERO, P. (1917): "Excavaciones en Punta de la Vaca y en Puerta de Tierra (Ciudad de Cádiz). Memoria de los trabajos realizados en 1916", MJSEA 12. Madrid.

(1918-1935): "Excavaciones en extramuros de la Ciudad de Cádiz", MJSEA 12, 26, 57, 76, 84, $95,99,117,122,129$ y 134. Madrid. 
RAMÓN, J. (1991): "El yacimiento fenicio de Sa Caleta", I-IV Jornadas de Arqueología Fenicio-púnica (Ibiza, 1986-1989). Trabajos del Museo Arqueológico de Ibiza, 24: 177-196. Ibiza.

—_ (1995): "Las ánforas fenicio-púnicas del Mediterráneo Central y Occidental", Col. lecció Instrumenta 2. Barcelona.

RAWLINSON, G. (1889): History of phoenicia. London.

RECIO, A. (1990): "La cerámica fenicio-púnica, griega y etrusca del sondeo de San Agustín", Servicio de Publicaciones de la Diputación Provincial de Málaga. Monografías 3. Málaga.

RODRÍGUEZ, J, C. (1974): Teoría e historia de la producción ideológica. Las primeras literaturas burguesas. Madrid.

ROMÁN, C. (1918-1927): "Excavaciones en la isla de Ibiza", MJSEA, 20, 43, 46, 58, 80, 91. Madrid.

RUIZ, A. (1994): "Vida, muerte y resurrección de los iberos", en La Antigüedad como Argumento (Beltrán y Gascó, Eds): 191-204. Sevilla.

SÁNCHEZ ALBORNOZ, C. (1956): España, un enigma histórico. 2 vol. Ed. Sudamericana. Buenos Aires.

SANOJA, M. (1984a): "La Inferencia en la Arqueología Social", Boletín de Antropología Americana 10.

- y VARGAS, I. (1984b): "Definición de conceptos para una arqueología social", Primer Simposio de la Fundación de Arqueología del Caribe. Viegues.

SCHUBART, H. (1976-1978): "Excavaciones en el Morro de Mezquitilla, 1976", Ampurias 38-40: 559-566.

(1979a): "Jardín. Informe preliminar de 1976 en la necrópolis de los VI-V a. C. ", Not. Arq. Hisp. 6: 153-173. Madrid.

— (1979b): "Morro de Mezquitilla. Informe preliminar sobre la campaña de excavaciones de 1976", Not. Arq. Hisp. 6: 177-218. Madrid.

(1988): "Alarcón", Madrider Beiträge 14: 172-188. Mainz.

(1990): "Hallazgos fenicios y del Bronce Final en la desembocadura del río Guadiaro (Cádiz)", Anuario Arqueológico de Andalucía, vol. II: 200-227. Sevilla.

- y ARTEAGA, O. (1986): "El mundo de las colonias fenicias occidentales", Homenaje a Luis Siret 1934-1984: 449-521. Sevilla.

- (1990): "La colonización fenicia y púnica", Historia de España, 1. Ed. Planeta. Barcelona.

SCHUBART, H. y NIEMEYER, H. G. (1969-1970): "Excavaciones paleopúnicas en la zona de Torre del Mar", Not. Arq. Hisp. XIII-XIV: 353-383. Madrid.

- (1976): Trayamar, Los hipogeos fenicios y el asentamiento en la desembocadura del río Algarrobo (EAE 90). Madrid, Ministerio de Cultura.

SCHUBART, H.; NIEMEYER, H. G. y LINDEMANN, G. (1972): “Toscanos, Jardín y Alarcón. La campaña de excavaciones de 1971", Not. Arq. Hisp. I: 11-41. Madrid.

SCHUBART, H.; NIEMEYER, H. G. y PELLICER, M. (1966): "La factoría paleopúnica en la desembocadura del río de Vélez (Málaga)”, IX CNA (1965): 250-254. Zaragoza.

(1969): Toscanos (EAE 66). Madrid, Ministerio de Cultura.

SCHULTEN, A. (1924 y 1945): Tartessos. Madrid.

SCHULZ, H. D. (1988): "Geologische bearbeitung der grabung in der hafenbucht von Toscanos", Madrider Beiträge 14: 142-154. Mainz.

SIRET, L. (1907): Villaricos y Herrerías. Madrid. 
SUÁREZ, A. (1987): "Excavaciones de urgencia en Villaricos (Cuevas del Almanzora). Memoria de gestión de las actividades arqueológicas de la provincia de Almería, 1987", Anuario Arqueológico de Andalucía, I, Sumario, 6: 9. Sevilla.

- (1988): "Excavaciones de urgencia en un solar sito en Villaricos (Cuevas del Almanzora). Memoria de gestión de las actividades arqueológicas de la provincia de Almería, 1988", Anuario Arqueológico de Andalucía, I, Sumario, 16: 8. Sevilla.

_ ; AGUAYO, P.; LÓPEZ CASTRO, J. L. y SAN MARTÍN, C. (1989): “Abdera: una colonia fenicia en el Sureste de la Península Ibérica", Madrider Mitteilungen 30: 135-148.

TARRADELL, M. (1950): "Hipogeos de tipo púnico en Lixus (Marruecos)", Ampurias XII: 186-189.

— (1951): "Las excavaciones de Lixus (Marruecos)", Ampurias XIII: 186-190.

(1952): "Sobre el presente de la Arqueología púnica", Zephyrus III: 151-174.

(1953): "Sobre la última época de los fenicios en Occidente", Zephyrus IV: 511-515.

(1955): "Lecciones de arqueología púnica", Caesaraugusta 6: 55-108.

(1956): "Las excavaciones de Lixus y su aportación a la cronología de los inicios de la expansión fenicio-cartaginesa en el Extremo Occidente", IV C. I. C. P. P. (1954): 789-796. Zaragoza.

(1958): "Notas acerca de la primera época de los fenicios en Marruecos", Tamuda VI, 1: 71-88.

(1960): Historia de Marruecos. Marruecos Púnico. Tetuán.

(1962): El país Valenciano del neolítico a la iberización. Valencia.

(1965a): "Prólogo", en D. Harden, Los Fenicios. Ed. Aymá, S. A. Barcelona.

(1965b): "Los fenicios en Occidente: Nuevas perspectivas", en D. Harden, Los Fenicios. Ed. Aymá, S. A. Barcelona.

(1975): "Schulten: Medio siglo de Historia Antigua de España", Papeles del Laboratorio de Arqueología de Valencia 11.

- y FONT, M. (1975): Eivissa cartaginesa. Barcelona.

TUÑÓN DE LARA, M. (1970): Medio siglo de Cultura Española. Ed. Tecnos. Madrid.

ULRREICH, H.; NEGRETE, M. A.; PUCH, E. y PERDIGONES, L. (1990): “Cerro del Prado. Campaña de 1989", Madrider Mitteilungen 31: 194-250. Mainz.

VARGAS, I. (1990): Arqueología, Ciencia y Sociedad. Ed. Abre Brecha. Caracas.

VELOZ, M. (1984): "La arqueología de la vida cotidiana. Matices, historia y diferencias", Primer Simposio de la Fundación de Arqueología del Caribe. Viegues.

VICENS VIVES, J. (1968): Aproximación a la Historia de España. Barcelona.

VILAR, P. (1947-1963): Histoire de L'Espagne. Librairie Espagnole. Barcelona. (1973): Historia marxista, historia en construcción. Barcelona.

VIVES, A. (1917): Estudio de Arqueología cartaginesa. La necrópolis de Ibiza. Madrid.

WARNING-TREUMANN, B. (1978): "West-phoenician presence on the Iberian Peninsula", The Ancient World, 1: 15-32.

WHEELER, M. (1961-1979): Arqueología de Campo. Fondo de Cultura Económica. México.

WHITTAKER, Ch. R. (1974): "The western phoenicians: colonisation and assimilation", PCPS 200, XX: 58-79. 